\title{
The Best of Both Worlds: Connecting Remote Sensing and Arctic Communities for Safe Sea Ice Travel
}

\author{
Rebecca A. Segal, ${ }^{1,2}$ Randall K. Scharien, ${ }^{1,3}$ Frank Duerden, ${ }^{1}$ and Chui-Ling Tam ${ }^{4}$
}

(Received 30 September 2019; accepted in revised form 22 June 2020)

\begin{abstract}
Northern communities are increasingly interested in technology that provides information about the sea ice environment for travel purposes. Synthetic aperture radar (SAR) remote sensing is widely used to observe sea ice independently of sunlight and cloud cover, however, access to SAR in northern communities has been limited. This study 1) defines the sea ice features that influence travel for two communities in the Western Canadian Arctic, 2) identifies the utility of SAR for enhancing mobility and safety while traversing environments with these features, and 3) describes methods for sharing SAR-based maps. Three field seasons (spring and fall 2017 and spring 2018) were used to engage residents in locally guided research, where applied outputs were evaluated by community members. We found that SAR image data inform and improve sea ice safety, trafficability, and education. Information from technology is desired to complement Inuit knowledge-based understanding of sea ice features, including surface roughness, thin sea ice, early and late season conditions, slush and water on sea ice, sea ice encountered by boats, and ice discontinuities. Floe edge information was not a priority. Sea ice surface roughness was identified as the main condition where benefits to trafficability from SAR-based mapping were regarded as substantial. Classified roughness maps are designed using thresholds representing domains of sea ice surface roughness (smooth ice/maniqtuk hiku, moderately rough ice/maniilrulik hiku, rough ice/maniittuq hiku; dialect is Inuinnaqtun). These maps show excellent agreement with local observations. Overall, SAR-based maps tailored for on-ice use are beneficial for and desired by northern community residents, and we recommend that high-resolution products be routinely made available in communities.
\end{abstract}

Key words: Arctic sea ice; Inuit knowledge; synthetic aperture radar (SAR); safety and navigation; remote sensing; cryosphere climate change

RÉSUMÉ. Les collectivités du Nord s'intéressent de plus en plus aux technologies qui leur fournissent de l'information au sujet de l'environnement de glace de mer à des fins de déplacements. La télédétection par radar à synthèse d'ouverture (SAR) est couramment utilisée pour observer la glace de mer, indépendamment de la lumière du soleil et de la nébulosité. Cependant, dans les collectivités du Nord, l'accès au SAR est restreint. Cette étude 1) définit les caractéristiques de la glace de mer qui exercent une influence sur les déplacements de deux collectivités dans l'ouest de l'Arctique canadien; 2) détermine l'utilité du SAR pour améliorer la mobilité et la sécurité quand vient le temps de traverser des environnements comportant ces caractéristiques; et 3) décrit les méthodes de partage de cartes établies à l'aide du SAR. Trois saisons sur le terrain (le printemps et l'automne de 2017, et le printemps de 2018) ont permis d'inciter les résidents à participer à une recherche locale guidée, là où les extrants appliqués ont été évalués par les membres de la collectivité. Nous avons trouvé que les données émanant des images du SAR éclairent et améliorent la sécurité de la glace de mer, l'aptitude à la circulation et l'éducation. L'information découlant de la technologie s'avère un complément désirable aux connaissances inuites en vue de la compréhension des caractéristiques de la glace de mer, dont la rugosité de la surface, la glace de mer mince, les conditions en début et en fin de saison, la bouillie de glace et la glace mouillée, la glace de mer rencontrée par les bateaux, et la discontinuité de la glace. Les données sur la glace de banc ne constituaient pas une priorité. La rugosité de la surface de la glace de mer était considérée comme la principale condition pour laquelle les avantages de la praticabilité déterminés au moyen des cartes établies à l'aide du SAR étaient substantiels. Les cartes indiquant la rugosité sont conçues en fonction de seuils représentant les caractéristiques de rugosité de la surface des glaces de mer (glace lisse/maniqtuk hiku, glace modérément rugueuse/maniilrulik hiku, glace rugueuse/maniittuq hiku; en dialecte inuinnaqtun). Ces cartes sont largement en accord avec les observations locales. Dans l'ensemble, les cartes établies à l'aide du SAR préparées en fonction des utilisations de la glace sont bénéfiques et désirées par les résidents des collectivités du Nord. Nous recommandons que des produits de haute résolution soient régulièrement mis à la disposition des collectivités.

Mots clés : glace de mer de l'Arctique; connaissances inuites; radar à synthèse d'ouverture (SAR); sécurité et navigation; télédétection; changement climatique de la cryosphère

Traduit pour la revue Arctic par Nicole Giguère.

\footnotetext{
${ }^{1}$ Department of Geography, University of Victoria, PO Box 1700, Station CSC, Victoria, British Columbia V8W 2Y2, Canada

${ }^{2}$ Arctic Eider Society, House 408B, Sanikiluaq, Nunavut X0A 0W0, Canada; and SmartICE Ice Monitoring and Information Inc., 261 Duckworth Street, St. John's, Newfoundland and Labrador A1C 1G9, Canada.”

${ }^{3}$ Corresponding author: randy@uvic.ca

${ }^{4}$ Department of Geography, University of Calgary, 2500 University Drive NW, Calgary, Alberta T2N 1N4, Canada

(C) The Arctic Institute of North America
} 
Ukiuqtaqtumiut nunallaat ihumagivallialiqtaat alruyaqtuqtut naunaiqhitiuyut hikum avatiinik aullaaqvighainit. Hanayauhimayut paqittitit (SAR) ungahiaqtumit qauyihautauyuq atuqtauvaktuq qauyihaiyaamik taryum hikuanik hiqiniilrumi nuvuyailrumilu; kihimi, atuqpagiamik SAR-nik ukiuqtaqtumi nunallaarnit ayuqhautiqaqpaktut. Una qauyihautik 1) ilittuqhitivaktuq hikum qanurininganianik aullaarvighanik malrungnit nunallaarnit Ualiniqhianit Kanatam Ukiuqtaqtuanit; 2) ilittuqhitivaktuq atuqpauhianik SAR-nik ikighilaarahuaqhugit naunaqtut aullaaqpagiamik taimaatut; taimaalu 3) qauhitivaktuq havauhirnik ilittuqhitigiingniqmik SAR-kut nunauyaliuqhimayainik. Pingahuiqtuqhutik nunainnaqmut (2017-18) aullaaqhimayut ilaupkaiyumaplugit nunallaarmiut ikkuaqtuiplutik qauyihaiyinut, talvani qauyihautigiyait qauyihaqtauhimayut nunallaarmiunit. Ilihimaliqtugut taimaa SAR-kut piksaliuqhimayainit naunaiqhitigivaktavut ihuaqhautigiplugu hikumi amirnaiqhimayaamik, aullaanginnarianigiamik, ilihaiyaamiklu. Naunaitkutat alruyaqtuqtunit ihariagiyauyut atauttikkuuriamik Inuit Qauhimayatuqainik hikum qanurininganianik maniittaaghainiklu, haattaaghaanik, hikunarigumi/hikunahaarumilu, imaqariaghaat taryumi hikumi, hikkutihimagumik qayaqtuqtut, piqaluyaillu. Hikum hinaanut naunaitkutaittuq irinigiyaunnginnami. Taryuq hikugaangat maniitkaangallu qauhitauvaktuq ihuilutautqiyatut aullaaqtunut SAR-kut nunauyaliuqhimayainit. Atuqnaqhihimayut maniilrunut nunauyat hanayauvaktut qauhitiplugit taryum maningnianik (maniktuq hiku/maniktuk hiku taimaaluuniit maniktuq hiku; maniilrulik/maniittutun hiku taimaaluuniit maniivyaktuq hiku; maniittuq hiku/manitpiaqtuk hiku taimaaluuniit maniilaq; uqauhiuyuq Inuinnaqtun). Hapkua nunauyat angiqhimagiittiarnikkut ilittuqhitiyuq nunallaarmiullu. Tamatkiumayumi, SAR-kut nunauyaliuqhimayait hanayauhimayut hikuhiuqtinut nakuuyut taapkununnga, ihariagiyauplutiklu talvanngat, ukiuqtaqtumi nunallaarmiunit taimaalu hanaquivaktugut takunnattiaqtunik ingilrutiliuqlutik hailiyaulutiklu nunallaarnit.

Uqauhilluit: Ukiuqtaqtumi Taryum Hikua; Inuit Qauhimayatuqait; Hanayauhimayuq Nunauyannguanik Paqitjutik; Amiqhiniq Nahittaqturniqlu; Ungahiaqtumit Paqittiniq; Hikuit; Hila Aallannguqpalliayuq

Жители северных общин всё больше интересуются технологиями которые предоставляют информацию об окружающей среде и проходимости по морского льду. Радиолокационное синтезирование апертуры (РСА) широко используется для наблюдения морского льда независимо от метеорологических условий; но, северные жители часто не имеют доступа к радиолокационным изображениям. Эта статья а) характеризует качество морского льда которое влияет на проходимость по льду в двух поселениях Восточной Арктики Канады, б) уменьшает неопределенность в навигации и передвижению по морскому льду, и в) описывает методы распространения карт для использования местными жителями. Во время трех экспедиций (2017/18), местные жители имели возможность участвовать и оценивать исследовательскую работу. Наши исследования говорят что РСА даёт знания о состоянии льда, а также проходимости и безопасности во время передвижения по морскому льду. Информация полученная от радиолокационных технологий может дополнить понимания местных жителей об определенных качествах морского льда. Включая шероховатости, состояние снежного покрова на поверхности, трещины, а также условия в начале/конце сезона и место нахождения морского льда на пути лодок. Информация о кромке припая не считалась приоритетом в этом регионе. Шероховатость имеет большое влияние на проходимость, и карты созданные с помощью РСА дают существенную пользу. Классифицированные карты шероховатости предназначены для разделения шероховатости на классы: ровный лед/maniqtuk hiku, лёд средней ровности/maniilrulik hiku, и шероховатый лед/maniittuq hiku (Inuinnaqtun диалект). Эти карты подтверждены местными наблюдениями. В общем, РСА карты приготовленные для использования на морском льде приносят пользу жителям северных общин, и мы рекомендуем чтобы высокотехнологичные карты по исследованию льда были доступны для практического применения жителями северных общин.

Ключевые слова: Морской лёд Арктики; Традиционные знания инуитов; Радиолокационное синтезирование апертуры; Навигация и безопасность; Радиолокационное наблюдение; Криосфера; Изменения климата

\section{INTRODUCTION}

Climate change has impacted the Arctic more than it has affected most other areas of the world (ACIA, 2005; Meier et al., 2014; Bush and Lemmen, 2019). Sea ice extent and thickness are decreasing, with the decline accompanied by a substantial loss of older multiyear ice (MYI; Markus et al., 2009; Comiso and Hall, 2014; Meier et al., 2014; Lindsay and Schweiger, 2015). First-year ice (FYI) now comprises $70 \%$ of sea ice in the Arctic basin, compared to $38 \%$ in the 1980 s (Stroeve et al., 2014). Many changes are a result of increased air temperatures (Overland, 2009; Bekryaev et al., 2010), increased ocean temperatures
(Steele et al., 2008), sea ice export out of the central Arctic during positive Arctic dipole anomaly phases (Wu et al., 2006), and decreases in albedo driven by MYI loss, which change solar heat-related feedback patterns (Perovich et al., 2008; Letterly et al., 2018). The open water season length is increasing (Markus et al., 2009; Stroeve et al., 2014), leading to changes in processes like ice deformation, fetch, and coastal erosion (Meier et al., 2014). Coastal areas are particularly impacted by climate change. Sea ice found within $50 \mathrm{~km}$ of land has decreased by $25 \%$ in the early summer over the Arctic, with the greatest declines in the East Siberian and Chukchi Sea areas ( $>40 \%$ ) (Bhatt et al., 2010). 
While changes in sea ice have impacts globally through large-scale weather and climate impacts and feedbacks, Arctic residents, industries, and ecosystems are impacted locally (Laidler, 2007; Laidler et al., 2009; Prowse et al., 2009; Stuckenberger, 2010; AMAP, 2011; Meier et al., 2014). Travel is a key activity impacted by both normal and changing sea ice conditions at seasonal and inter-annual scales (Dammann et al., 2018b). In this context, hazards are conditions or events that have the potential to harm people, causing damage that is physical, psychological, and possibly includes loss of life (Ford et al., 2008). The risk (degree of hazard exposure) associated with travel is impacted by environmental conditions (e.g., time of year and ice type), social conditions (e.g., degree of familiarity with the area), reliance on technology and understanding of climate-related changes, and the potential consequences of disaster (Ford et al., 2008; Lépy, 2008; Eicken and Mahoney, 2015). Furthermore, trafficability, hazards, and risks depend on the type of sea ice use and, as they are associated with particular sea ice conditions, are unevenly distributed in space and time. For example, safety concerns associated with shipping activities where travelers navigate through ice are different than those encountered by Inuit traveling on ice (Laidler et al., 2009; Stephenson et al., 2011; Eicken and Mahoney, 2015; Dammann, 2017; Rolph et al., 2018). Furthermore, the hazards associated with increasingly dynamic ice conditions are likely to have unequally distributed impacts among shipping, industry, and community stakeholders (Dowsley et al., 2010; Bell et al., 2014; Pizzolato et al., 2014; Dawson et al., 2017).

As major social changes and natural variability in sea ice conditions are further compounded by climate change, northern communities are increasingly interested in scientific information designed to improve safety by reducing uncertainty (Laidler et al., 2011; Panikkar et al., 2018). Inuit traditional, current, and future knowledge (Inuit knowledge, or IK) contains extensive information about the sea ice environment obtained from personal experiences as well as knowledge passed through generations. IK guides Inuit and others who have learned from Inuit to navigate safely in the sea ice environment, where many people hunt and fish for subsistence purposes, travel to cabins, and maintain strong cultural relationships with their environment. However, in many communities there is a gap in knowledge transfer that has resulted in younger generations possessing less IK than elders (Ford, 2005; Ford et al., 2006b; Laidler, 2007; Laidler et al., 2011). With changes including the development of settled communities, wage economies, a variety of lifestyle options, and the adoption of technology, the use of sea ice is different and more limited than in the past (Ford et al., 2006a, b; Heyes, 2011; Laidler et al., 2011; Brinton, 2018; Panikkar et al., 2018). Consequently, younger people are often more reliant on technology that complements their IK (Laidler, 2007), although IK remains imperative for staying safe should technology fail (Ford et al., 2006b; Laidler et al., 2011; Do.G. Clark et al., 2016; Panikkar et al., 2018). For example,
Ford et al. (2006b) note that when technology works well, the use of a GPS means that navigational IK is not necessary; however, vulnerabilities are exacerbated if the GPS fails and people do not know IK navigation. As such, technology can help to buffer risks, while also creating new vulnerabilities.

Furthermore, the increase in unpredictable and variable weather makes sea ice conditions more difficult to predict using IK (NTI, 2001; Krupnik and Jolly, 2002; Ford and Smit, 2004; Nickels et al., 2005; Ford et al., 2006a, 2008; Laidler, 2007; Druckenmiller et al., 2009; StammlerGossmann, 2010; Rolph et al., 2018). Search and rescue events in Nunavut more than doubled between 2006 and 2015 due to factors like environmental exposure, loss of IK and changes in culture, economic stress, and more powerful and complicated equipment (Dy.G. Clark et al., 2016; Nunavut Emergency Management, 2017). The ability to identify key sea ice features and assess seasonal development is critical for reducing travel time, fuel cost, equipment deterioration, and risk (Ford et al., 2008; Laidler et al., 2009, 2011). Sea ice hazard and obstruction information is already accessible for operational and industrial industries (e.g., shipping) by Arctic nations in the form of sea ice charts (Bertoia et al., 1998), which are products derived from satellite remote sensing combined with ancillary data sources. However, information available to northern communities is currently limited and needs to be tailored differently to be useful for communities. For example, finer spatial scale, different timings, and removal of jargon and technological limitations such as delivery format are seen as beneficial (Laidler et al., 2011; Bell et al., 2014).

Microwave remote sensing is particularly helpful for Arctic sea ice monitoring because imagery can be captured independently of sunlight and cloud cover, conditions that severely limit optical sensors (Bertoia et al., 1998; Teleti and Luis, 2013). Synthetic aperture radar (SAR) is an active microwave system capable of providing image data at spatial resolutions of $\sim 1-100 \mathrm{~m}$ and swath widths of $\sim 30-500 \mathrm{~km}$. Processed images have variations in tone that correspond to the proportion of energy backscattered and received by the SAR. These image tones are a result of the sensor parameters (e.g., incidence angle, transmit/ receive polarizations, controllable modes of various spatial resolutions and swath widths), as well as surface properties. Backscatter is sensitive to target dielectric property contrasts; for example, backscatter may occur at the snowice interface. For surface scattering, the backscatter is sensitive to the number of surface components (i.e., surface roughness) at scales relative to the SAR wavelength $(\sim 5 \mathrm{~cm})$. Volume scattering can also occur when the signal scatters within a volume, such as air bubbles inside freshened ice (Hallikainen and Winebrenner, 1992). SAR data reveal sea ice parameters like extent, type, deformation, drift, melt state, and surface flooding (Chan and Koo, 2008; Dierking, 2013; Teleti and Luis, 2013; Ersahin et al., 2014; Scharien et al., 2014). Sea ice thickness from SAR has been investigated 
(Kim et al., 2012), though the radar signal does not penetrate the ice, and ice thickness is usually inferred from ice type, as revealed by image tone and texture variations. Accessibility to SAR data is increasing, with the European Space Agency's Sentinel-1 constellation of two polarorbiting satellites offering frequent and, importantly, openaccess data. Recent and expected launches of additional SAR satellites such as the RADARSAT Constellation Mission (RCM) in 2019, and the National Aeronautics and Space Administration (NASA) - Indian Space Research Organization (ISRO) Synthetic Aperature Radar (NISAR) mission in 2021, may increase accessibility, depending on policies regarding access.

Arctic residents, many of whom are Inuit, have expressed interest in accessing information from SAR imagery to complement their understanding of changing sea ice conditions and to plan livelihood activities (Druckenmiller et al., 2009; Gauthier et al., 2010; Laidler et al., 2011; Bell et al., 2014). Many of the traditional indicators used to assess sea ice quality (e.g., winds, MYI, openings such as cracks, leads and ice edges), can be studied using SAR images (Laidler et al., 2011). SAR has the potential to be used in combination with modern and traditional information sources to create baseline datasets, support safe travel to hunting sites and between communities, and help preserve the cultural wellbeing of Arctic coastal community residents who use the sea ice as an extension of the land (Nickels, 2005; Laidler, 2007; Aporta, 2009; Laidler et al., 2011; Lindsay et al., 2012; Meier et al., 2014; Dammann et al., 2018b).

Druckenmiller et al. (2013), Eicken et al. (2011), Laidler et al. (2011), and Bell et al. (2014) provided SAR imagery images to the communities of Utqiagivik (formerly Barrow, Alaska); Cape Dorset, Igloolik, and Pangnirtung (eastern Nunavut); and Nain and North West River (Labrador), respectively. They provided SAR imagery in print format and sometimes digital format, and typically images were from RADARSAT-1/2, ERS-2, marine X-band radar sensors, or a combination of these sensor types. The RADARSAT-1/2 SAR sensors operate at the same C-band frequency as Sentinel-1, though unlike Sentinel-1, access to new images is restricted and costly. Users generally found the SAR images useful when treated like photos rather than datasets. Alaskan residents used the images and short videos of image time-series to identify potential hazards, locate the sea ice edge, track ice movement, discriminate between rough and smooth ice, and plan excursions. Druckenmiller et al. (2013) found that marking trail locations on SAR images allowed Utqiagivik hunters to more easily recognize locations. Eastern Nunavut hunters look for information about snow thickness, ice weakness (fracture potential), current-induced thin ice, ice density, and ice thickness (Laidler et al., 2011). SAR imagery improved trip safety and planning by aiding identification of unstable or poor ice, ice roughness, ice type, pressure ridges, as well as ice that impacts boats. The hunters expressed a need for higher spatial and temporal SAR resolutions for resolving cracks, leads, polynyas, ice thickness, and daily ice growth. Access to SAR training and easier-to-interpret, colour-coded products that could be annotated were also desired. In Labrador, the SmartICE program's initial community consultations revealed that hunters also want information on the locations of surface ice and snow roughness, open water, water-on-ice and melt pond ice lenses, landfast, shear, and pack ice, and thin ice areas (Bell et al., 2014). SAR images were combined with in-situ thickness samples and manually classified by locals to resolve small-scale features. A combination of RADARSAT-2 ScanSAR Narrow, Standard, and Fine mode products were used. While these specially tasked, higherresolution images and continuous local input make for highquality products, we note that the outputs are dependent on continuous resources.

Other studies in Alaska and the Canadian Arctic have investigated SAR use in the context of sea ice safety and trafficability conditions. For Alaska, Dammann et al. (2017, 2018a, b, 2019) utilized advanced SAR and techniques such as polarimetry and interferometry for assessments of trafficability - the ability to safely and efficiently navigate within sea ice environments. They created quantitative assessments of ice trafficability where bearing capacity, surface conditions, and ice motion were investigated. Ice quality was described using nine ice variables: timing and duration, stability, fracture potential, thickness, microstructure and state variables, pre-existing defects, extent, roughness, and snow and surface water conditions. SAR-derived products showing surface characteristics were shared with the communities over the course of their research project. For the Victoria Strait region of the Canadian Arctic Archipelago (CAA), detection of sea ice roughness using Sentinel-1 and the optical Multi-angle Imaging SpectroRadiometer (MISR) was evaluated using airborne-derived LiDAR data of sea ice surface heights (Segal et al., 2020). Segal et al. (2020) found a strong correlation between roughness and Sentinel-1 backscatter in areas of FYI $(r=0.76)$ and a strong correlation between roughness and a MISR-derived roughness index in areas of MYI $(r=0.68)$. They suggest that both satellite products be integrated to produce community-relevant roughness information including FYI and MYI. Cafarella et al. (2019) also found a strong correlation between airborne laser scanner-derived FYI surface roughness and backscatter from C-band RADARSAT-2 $(r=0.86)$.

In general, sea ice information needs can vary widely, even between communities in close proximity to one another (Ford et al., 2008; Laidler and Elee, 2008; Laidler and Ikummaq, 2008; Laidler et al., 2008; Fisheries and Oceans Canada, 2012). These dissimilarities make it necessary to determine which impediments to sea ice trafficability individual Arctic regions and communities face, the ability of SAR to address these impediments, and the spatiotemporal scales at which sea ice information is helpful. In this study, we 1) define the sea ice features that influence trafficability, as encountered by the residents of Kugluktuk and Cambridge Bay; 2) identify the utility of 


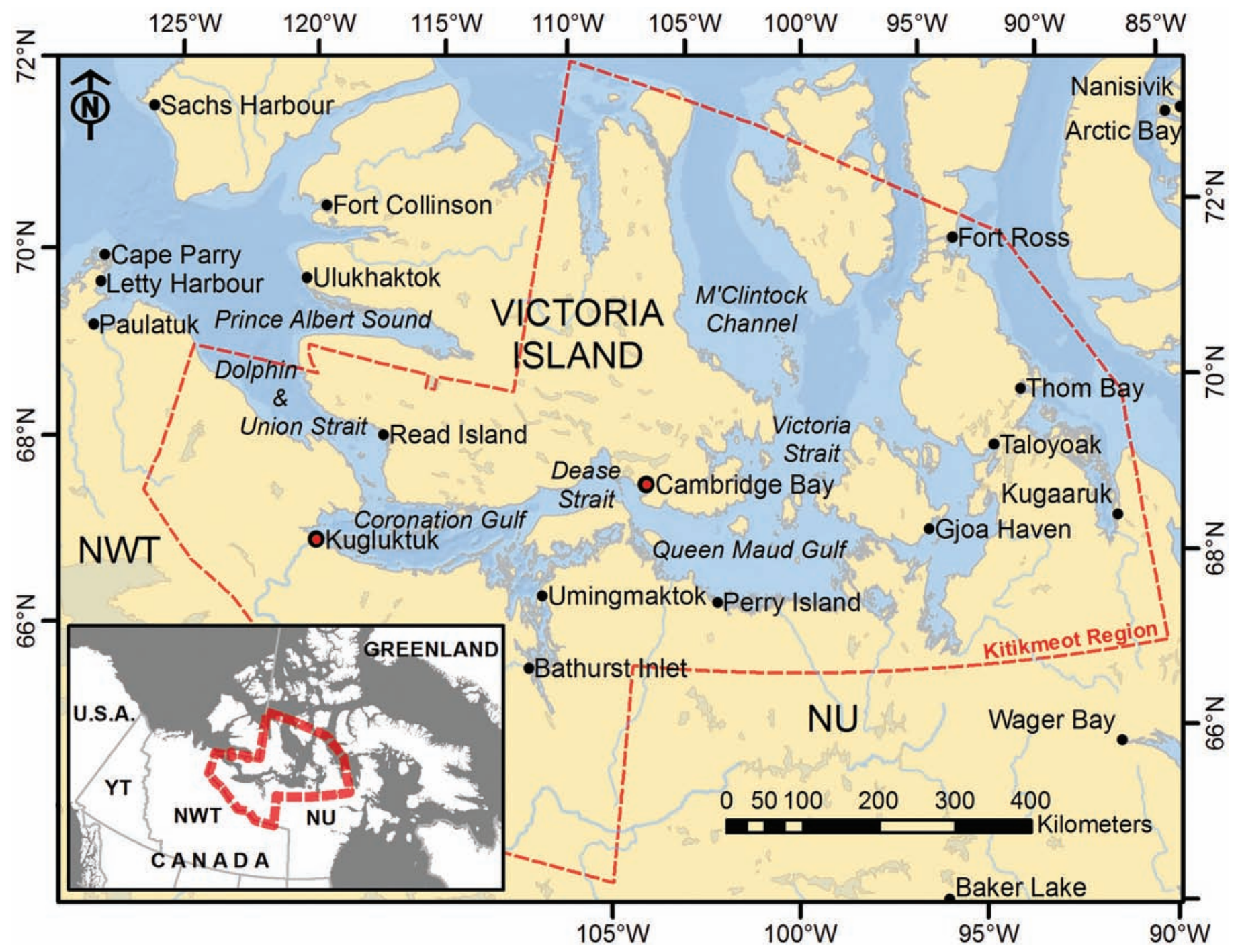

FIG. 1. The locations of Cambridge Bay and Kugluktuk (red dots) in Nunavut's Kitikmeot Region Subdivision (red dashed lines; from the 2017 Canadian census). Other populated places are shown as black dots.

SAR for reducing uncertainty associated with traversing environments with these features; and 3) describe the methods used to share SAR-based products in ways that are useful to these communities. We emphasize the use of Sentinel-1 SAR imagery because of its open-access format, which enables easy dissemination to users.

\section{STUDY AREA}

The marine areas used by Kugluktuk (Qurluktuk) and Cambridge Bay (Iqaluktuuttiaq) residents are situated in the Kitikmeot administrative region of Nunavut in the Canadian Western Arctic (Fig. 1). The Western Canadian Arctic, and particularly the CAA, has a unique ice regime where community ice information needs remain undefined (Howell et al., 2009). The region has nearly $100 \%$ landfast sea ice in late winter and spring and contains FYI, which may form during calm periods (low wind or currents) resulting in smooth areas, or becoming deformed FYI by wind or wave action. Some parts of the CAA also contain MYI, which has a hummocky surface. The marine portion of the Kitikmeot includes Larsen Sound, Queen Maud Gulf, Coronation Gulf, and Bathurst Inlet. Kugluktuk, the westernmost community in Nunavut, is located on the north coast of mainland Canada next to Coronation Gulf and is on the western edge of the Coppermine River mouth. The Hamlet of Kugluktuk has $\sim 1500$ residents (Statistics Canada, 2017a). Cambridge Bay is located on the southeast coast of Victoria Island, adjacent to Dease Strait. The Hamlet of Cambridge Bay, with a population of 1800 residents (Statistics Canada, 2017b), is a growing transportation and administrative centre and a regular stopover for vessels traveling the Northwest Passage (Calihoo and Romaine, 2010). The majority of people in Kugluktuk and Cambridge Bay are Inuk, at $90 \%$ and $81 \%$ respectively, and the dominant Inuktut dialect of both communities is Inuinnaqtun (Statistics Canada, 2017a, b).

Like most Arctic communities, residents in both Kugluktuk and Cambridge Bay are highly dependent on 
sea ice for travel and subsistence (Aporta, 2009; Calihoo and Romaine, 2010; Johnson and Arnold, 2010; Panikkar et al., 2018). Hunters and trappers travel to cabins and other communities, supply their families and networks with traditional food, and professional guides accompany tourists and researchers on sea ice. Both communities have cell phone service, and many residents use snowmobiles and other technological devices or products like weather reports, InReach, and GPS (Panikkar et al., 2018). Additionally, with the presence of the Canadian High Arctic Research Station (CHARS), relationships between scientists and local residents and research in the Kitikmeot are increasingly encouraged.

Seasonal sea ice is a dominant feature of the Kitikmeot marine environment for more than nine months of the year. The average date of freeze-up to $50 \%$ ice concentration between 1982 and 2010 was 22 October for both communities, while breakup was 2 July in Kugluktuk and 16 July in Cambridge Bay, with an open water season in-between (CIS, 2011). Landfast FYI dominates Coronation Gulf, Dease Strait, and Dolphin and Union Strait, and MYI is usually present in M'Clintock Channel and, to a lesser extent, Queen Maud Gulf (CIS, 2011). While floe edges are adjacent and economically important to many Arctic communities, near Kugluktuk and Cambridge Bay the landfast sea ice approaches $100 \%$ concentration.

\section{METHODS}

\section{Research Approach and Community Data}

In this study, IK was connected with science to 1) identify information needs regarding improved sea ice trafficability, and 2) evaluate the effectiveness of SAR for reducing uncertainty associated with these needs. This study was built upon collaborative relationships with northern residents and organizations developed by a member of the research team during prior visits for a different project and through organizations that have connections in the communities (the Arctic Eider Society, Ocean Networks Canada, the University of Victoria, and the Canadian Ice Service [CIS]), as well as upon the existing literature.

We engaged with residents of Kugluktuk and Cambridge Bay formally and informally to create a locally guided research project with an applied output product, as recommended by Ford et al. (2018), Grimwood et al. (2012), and Tondu et al. (2014). Engagement primarily occurred during three community visits during the spring and fall 2017 and spring 2018 and was sustained remotely via phone, email, and social media. We initiated the project by asking scoping questions about satellite imagery and travel information needs during the first field season, which consisted of 1-2 members of the research team spending three weeks in Cambridge Bay followed by two weeks in Kugluktuk. Research priorities were developed and further expanded through interviews, workshops, and discussions with individuals and organizations as the project progressed. In subsequent field seasons, three public meetings were held: two in Kugluktuk and one in Cambridge Bay. The public meetings had varied levels of participation (from several people to $\sim 70$ people); we suspect that attendance was influenced by other community events. These were the only events for which we hired translators. Two informational evening sessions held in each community at local grocery stores extended discussions to those interested and informed the community of project goals. Hunters and trappers organizations (HTOs), hamlets, and the Kitikmeot Inuit Association (KIA) were also invited to provide guidance and help develop research design and local protocols, with the HTOs playing the largest role. Informal activities (e.g., attending local events, sharing conversations over tea, sewing with others) were also very successful for developing relationships and gaining local insights.

We conducted semi-structured interviews on the topics of sea ice trafficability and SAR-based map evaluation during all field visits (Table S1). Participant recruitment focused on residents aged 14+ who use sea ice for travel and subsistence. A few interviews were also held with people who no longer travel or have less experience but were interested in participating and knowledgeable about the environment. All interviews involved viewing greyscale SAR-based maps created specifically for the interview process and included an optional participatory mapping component. During the first field season, we also brought Sentinel-1 red-green-blue colour composite images in which the colours corresponding to different transmitreceive polarization parameters. These images were not often presented because of their complexity and the affinity of hunters to the greyscale maps. The second and third field seasons involved also viewing the classified SARbased maps that were created to show sea ice roughness. The optional participatory mapping component was mainly done by drawing on the printed SAR-based maps (some smaller maps containing only land outlines were also used) and involved marking important places, places known to be hazardous (e.g., thin sea ice, rough sea ice) or areas or routes that are good for travel (consistently or inconsistently smooth sea ice).

Potential interviewees were suggested by organizations including the HTOs, hamlets, and the KIA; other residents (snowball sampling); or were directly encountered. Interview and workshop compositions were flexible, with one to seven interviewees. Some interviewees were present at more than one session. In total, 47 interviewees participated formally over 37 sessions that included seven workshops ( $>2$ interviewees), with 20 people participating formally on more than one occasion. Workshops covered similar topics but involved increased discussion among interviewees and were typically longer sessions. Nineteen interviewees were currently living in Kugluktuk, of whom two were women, and 28 were currently living in 
Cambridge Bay, of whom five were women. Audio was recorded during all but two interviews during which notes were taken instead, as well as during the workshops, once consent was obtained. Sea ice excursions in both spring and fall were conducted to allow residents to identify and discuss specific areas or features related to sea ice, travel, and trafficability. In discussions, contributors used descriptions of travel instead of the more formal term "trafficability" used here for succinctness. Three formal on-ice interviews were conducted over four sea ice excursions, one per community in early and late winter (November and May). These trips, though they were approximately 2-6 hours and remained relatively close to town, assisted discussions of particular locations (e.g., main routes), ice features (e.g., rough ice blocks), and their relationships to SAR-based maps. We also navigated to areas of smooth, moderately rough, and rough sea ice areas (as identified in classified SAR-based sea ice maps), to discuss the map accuracy.

We analyzed interview transcripts using thematic analysis and coding in NVivo Pro 11. Codes were drawn from thematic information patterns encountered in interviews and attached to relevant interview text (e.g., coded "MYI," "rough ice," "access [to remote sensing]"), then aggregated or separated as required during analysis and assembled into themes (e.g., sea ice surface roughness) as in Nowell et al. (2017). The codes were based on emerging interview themes, which were also influenced by the questions asked. Naturally, there is considerable overlap among the themes identified, since sea ice information was discussed without categorization by community members. Results were not explicitly verified with community members, although we did try to review and expand upon our findings as the study progressed. Interviewees are not referred to by name throughout the analysis, as some contributors did not give permission to disclose personal information, and we do not want to give less weight to their statements. However, contributors who gave permission to share their names are identified in the supplementary file.

\section{SAR-based Maps}

This study used data from Sentinel-1 SAR, which has a temporal revisit frequency of 2-4 days for the marine areas of Kugluktuk and Cambridge Bay (ESA, 2018b). Specifically, extra-wide (EW) format images were used, which are a Standard Level 1 Product with $40 \mathrm{~m}$ resolution (ESA, 2018a). Sentinel-1 provides imagery of a higher resolution than most freely available satellite images, although it cannot capture the small individual marine features that are often important for sea ice trafficability. Hereafter, references are made to Sentinel-1 SAR, but the more general term "SAR-based maps" is also used because other SAR sensors could provide similar information.

We selected the SAR images for processing based on their timing, with 2-4 Sentinel-1 images from winter and shoulder seasons (freeze-up and melt) per community processed as greyscale SAR-based maps (Table S2). We focused on winter period images because the ice is landfast and thick, but shoulder season images also served as discussion points for seasonal trafficability hazards. Here, the term greyscale is used to denote maps based on Sentinel-1 images that have undergone standard processing to backscatter intensity (Fig. 2). The HH-polarization band (horizontal transmit and receive polarizations) was used since it is sensitive to ice type and surface roughness, and the $\mathrm{HH}$ band data from smooth sea ice in this region are above the sensor noise floor (Scharien et al., 2017). Preprocessing steps included 1) thermal noise removal, 2) calibration (gamma-nought), 3) speckle filtering (Lee $7 \times 7$ ), 4) conversion to deciBel (dB), and 5) map projection. For greyscale map production, we applied a histogram stretch to the data and added mapping elements such as a scale bar. Greyscale SAR-based maps were used as engagement tools and visual demonstrations of the capabilities of SAR. Printed copies were left in the communities in the spring, and digital copies were distributed in winters $2017-19$ by email and social media.

After the first field season, a thresholding technique was applied to winter SAR images to show degrees of sea ice roughness (see Discussion). These sea ice roughness maps are called "colour-coded" SAR-based maps. If not specified, the term "SAR-based maps" refers to both the greyscale and colour-coded map products. During discussions of the maps in interviews and workshops, significant effort was made by the research team to specify the map date and type (greyscale or colour-coded) out loud, so that observations could be accurately paired with the correct SAR-based map.

\section{RESULTS}

\section{Community Changes Impacting Sea Ice Use}

The interviews highlighted social changes and the adoption of modern technologies as ways that travel and safety are changing. People have varied degrees of competence with the skills necessary for sea ice travel, and most spend less time on ice than previous generations. Residents of all ages from both communities cited an IK gap between young people and elders, noting that many search and rescue events are caused by people getting lost or being inadequately prepared to travel safely. The majority of interviewees work jobs or split their time between multiple interests, reducing the time available for sea ice use. Purchasing and maintaining equipment like snowmobiles necessitates participation in the modern economy. Growing populations result in augmented hunting pressure near the communities and, when animals do come near town, opportunistic hunters may encounter hazards for which they are not equipped. The hunters who choose to travel longer distances to find animals do so in an increasingly uncertain sea ice environment, while increases in community populations also make it more difficult to 


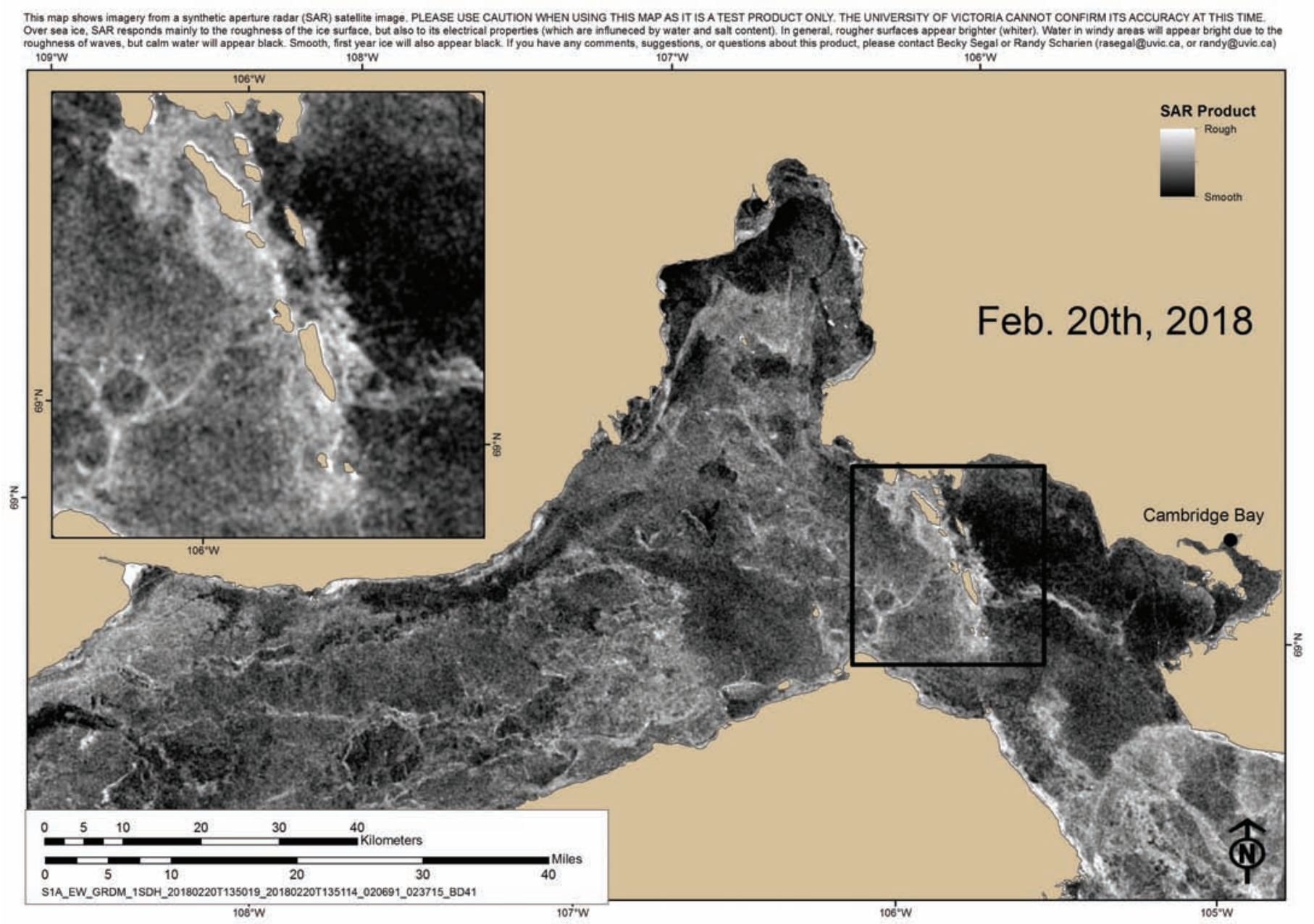

FIG. 2. Example of a greyscale Sentinel-1-based map of sea ice brought to Cambridge Bay.

track who has returned safely. Another cultural change is also occurring now that some women are hunting, which is traditionally a male task, and becoming sea ice guides.

Interviewees emphasized the prevalence of technology and its rapid change. They discussed the use of technology before, during, and after travel, including SAR-based maps, snowmobiles, boats, all-terrain vehicles, GPS, InReach, cell phones, weather information, radio, and social media. Technologies have changed the way travel is conducted and have had mixed impacts on travel safety. For example, snowmobiles, unlike dog teams, can break down and leave travelers stranded. However, they allow for faster travel while carrying more supplies and do not require looking after in the same manner as dogs. Many people use GPS, weather reports, and traditional knowledge and, as described by a woman in Kugluktuk, "combine it all together and ... have the best of both worlds. I think that's what people should be learning." Most interviewees pointed out the ability of community members to adapt to widespread technological change and wanted access to, and the choice of, modern technology.

\section{Sea Ice Changes Impacting Use}

If you're going to develop a map, [it] should say somewhere on the map that these are danger areas. And that could be used in schools to educate the children at a younger age, and young people who are just starting to go out on the land and don't understand it. I can see that being very useful, in the sense that they'll understand the danger zones, or danger areas. Because unless you ask somebody "where's the danger areas?"... you'll get into trouble.

Cambridge Bay hunter

Interviewees provided information about sea ice conditions, related community concerns, as well as the role of technologies in adaptation. The ice conditions relevant to trafficability include the following features and seasonal regimes arising from thematic analysis and interviewee terminology or structure:

1) Smooth FYI: seasonal sea ice that grows in calm conditions. 
2) Moderately rough and rough FYI: sea ice surface has embedded slabs of broken ice, typically $\sim 15-60$ $\mathrm{cm}$ thick and less than 1 to over $6 \mathrm{~m}$ high. This class includes pressure ridges. Ice slab density and size varies. FYI may be thicker (piled up) or thinner (if impacted by snow insulation) than smooth sea ice.

3) MYI: has a smooth and bumpy (hummocky) surface. MYI is often very thick ice with low salinity. If next to FYI, there can be a significant drop in surface height at the transition between floes (referred to as "skateboard style" by one interviewee) that is often hidden by snow cover.

4) Snow on sea ice: from precipitation. Wind causes snow buildup behind ice pieces and makes long snowdrifts.

5) Thin ice: ice that will not hold the weight of a snowmobile (or sometimes a person). Its occurrence is often related to the season or to fast-moving water (ocean current or river outflow) that thins the ice from the bottom.

6) Early ice: a seasonal regime associated with freeze-up that begins when the ice becomes safe for travel and ends when winter conditions persist. Sea ice is thin and unstable. Its formation influences sea ice conditions throughout the ice season.

7) Late ice: a seasonal regime associated with breakup that begins when the ice deteriorates by rotting in strong current or nearshore areas. It accumulates sea ice fractures and surface slush and water. Late ice is broken by winds and tides, until ice chunks float freely. This ice condition ends when marine boat travel becomes possible.

8) Slush and water on ice: ice-coloured and light blue ponds contain surface water. Dark blue, muddy looking, or grey-black ponds indicate melt holes. Slush, water, or refrozen melt ponds may disguise areas of thin ice.

9) Ice encountered by boats: boating begins when small local boats are launched in the ocean in spring and ends when sea ice blocks boat travel. Boaters travel through and over sea ice, and also pull boats on sea ice using snowmobiles.

10) Ice discontinuities: includes cracks, leads, and pressure ridges. Cracks are narrow, typically long fissures through the sea ice. Pressure ridges are either fractures with open or snow-covered water bordered by piled up sea ice, $\sim 1.2 \mathrm{~m}$ to $4.5 \mathrm{~m}$ in height (we refer to these as "Type 1"), or ridges that form when sea ice releases pressure and buckles upward, which can be taller ("Type 2"). Leads are wide splits through the sea ice, generally not crossable. Fractures appear deceptively narrow when ice edges are thin or snow covered. They can shift and open and close with the tide, especially in spring.

The occurrence of these ice conditions is described in Table 1. Note that some of these features and seasonal regimes overlap; for example, ice may be thin early in the season.
Myriad changes in these sea ice features were noted during interviews, with both Kugluktuk and Cambridge Bay interviewees reporting that environmental changes are creating increased uncertainty about sea ice conditions and trafficability. Sea ice feature usage and changes are described in Table 2, with additional detail provided in the supplementary file.

\section{Evaluation of SAR-based Maps}

This [referring to the SAR-based maps] is fantastic; this is incredible. And this very much is the reality. Yes, it's very much indicative of what you see.

Cambridge Bay hunter

\section{Features Impacting Travel}

Community members expressed great interest in SARor technology-based information about all the sea ice conditions from Table 2 that impact safety and trafficability. A comparison between traditional practices of information gathering and the information desired for safe travel is detailed in Table 3. The evaluation of SAR-based maps and realized or perceived benefits are given in Table 4 . Information needs are not equally important because some features are more easily avoided or mitigated than others. Sea ice surface roughness was identified as the main ice condition where benefits to trafficability from SAR-based mapping were regarded as substantial. Rough sea ice makes travel slow, difficult, hazardous, and expensive. However, while both greyscale and classified SAR-based maps show good agreement with local understanding and observations of sea ice roughness, a decorrelation was observed by interviewees for 1) areas of freshened ice influence (i.e., MYI and riverine output areas), or 2) areas of heavy snow. The first discrepancy is due to volume scattering in low-salinity ice and the second is because C-band SAR penetrates through cold, dry snow to the ice surface (Segal et al., 2020).

Detection of thin ice areas, considered a high information priority, is not reliably done using C-band SAR. In winter, thin ice areas can occur due to bottom erosion by currents, though the surface portion of the ice detected by the SAR remains largely unchanged. Ice experts can sometimes infer thickness by qualitatively identifying a newly forming sea ice type, though signature overlap can still occur (e.g., smooth ice and calm, open water). Consequently, we developed a supplemental dataset showing areas identified by locals as typically having thin ice or open water (Fig. 3) and placed a warning above the derived maps (Fig. 2).

\section{Users and Experience}

Overall, 91\% of interviewees wanted SAR-based maps. These maps were considered useful by residents who use the sea ice for hunting and traveling because the maps reveal sea ice surface and ocean conditions in areas not well traveled yet that season (Table 4). A majority of 
470 • R.A. SEGAL et al.

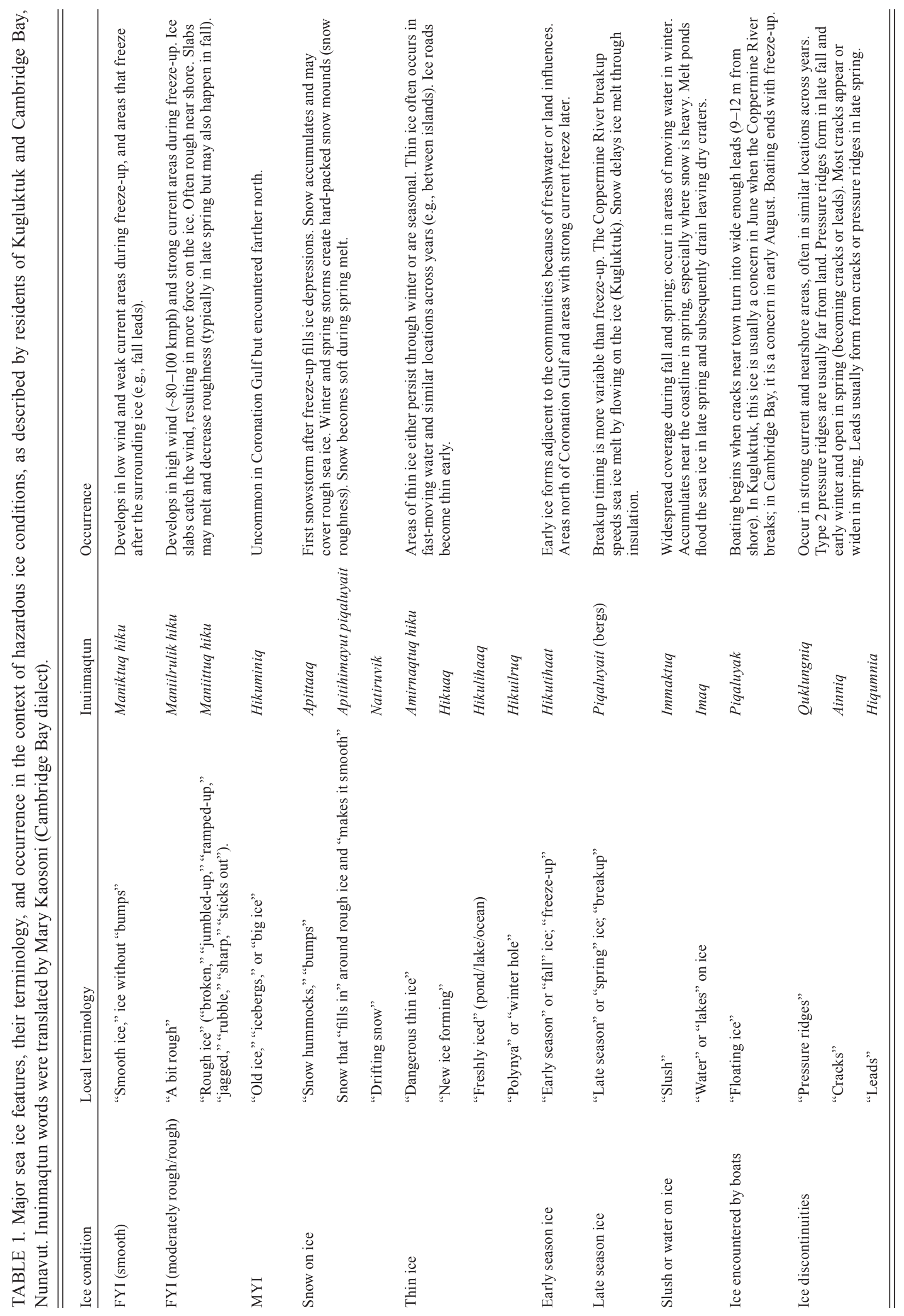


TABLE 2. Sea ice feature use and the impacts of change on use, as described by residents of Kugluktuk and Cambridge Bay, Nunavut. Features are described in the text and Table 1.

\begin{tabular}{lll}
\hline \hline Feature & Usage & Changes and impacts on use \\
\hline FYI (smooth) & $\begin{array}{l}\text { Facilitates rapid snowmobile travel }(\sim 50-110 \mathrm{kmph}), \text { good } \\
\text { fuel efficiency, and light wear on equipment. }\end{array}$ & Becoming rougher. \\
FYI (moderately rough/rough) & $\begin{array}{l}\text { Slow and difficult travel }(\sim 5-30 \mathrm{kmph} \text {; zigzag and shorten } \\
\text { tow lines). Hard on equipment. Lower fuel efficiency. Hard to } \\
\text { navigate in dark or bad weather. Polar bear range area. Good } \\
\text { for emergency shelters. Less predictable travel. Increased risk } \\
\text { of accidents and breakdowns. }\end{array}$ & $\begin{array}{l}\text { May be rougher in recent years. Exacerbates risk of accidents } \\
\text { freeze-up may cause formation to occur during windier time }\end{array}$ \\
\hline
\end{tabular}

MYI

Snow on ice

Thin ice

Early season ice

Slush or water on ice

Ice encountered by boats

Ice discontinuities

\section{Smoother than rough FYI but rougher tha
bear range area. Good for drinking water.}

Modifies ice surface to smoother or rougher. Insulates sea ice and controls ice thickness. Fall snow makes travel easier. Snow accumulation may allow rough ice to be trafficable. Rough snow and soft snow both decrease trafficability.

Risk of falling through the sea ice. Causes travelers to hug shorelines.

Use begins when sea ice is $5-15 \mathrm{~cm}$ thick (risk-tolerant or experienced travelers near communities) or $\sim 0.6-0.9 \mathrm{~m}$ thick (farther from land). On-ice travel is preferable to terrestrial travel because of lack of snow cover.

Use ends when cracks or leads become too dangerous (June and July). Most travelers stop ice use when it is difficult to access from shore but is still safe.

Melt holes and deep melt ponds indicate quickly thinning sea ice; they need to be avoided and deter most people from travel. Snowmobiles can get stuck in slush or water, break through refrozen melt pond ice lids, and skid or stop running if the belt gets wet. Sleds may spin because of the loss of friction over melt ponds. Travel in cool evenings may be easier when the soft slush and snow is firmer.

Must plan boat travel to avoid being trapped inside or outside the community by ice. A longer boating season is beneficial for people with boats, but not for on-ice activities. Must be aware of shifting ice (particularly MYI) as it causes waves dangerous to small vessels.

Used as landmarks to identify locations. Regularly crossed when narrow, otherwise crossed using a natural sea ice bridge (transcurrent-style shift that leaves a bridge-like structure across the crack or fault), making a sea ice bridge (a last resort), or by jumping a snowmobile (water skipping). Location to hunt ocean animals. It is possible to fall through fractures into open water (experienced by several participants); precautionary flotation suits may be used in spring. Can be difficult to see in darkness or poor weather.
Possible changes due to winter storm frequencies.

Thinning connected to warmer ocean or changing snowfall patterns. New and larger open-water areas now found; e.g., Cape Krusenstern area.

Delayed or prolonged: historical use was in September and October, but is now in November and December. Observations of under-ice slush not developing due to warmer water (early season ice now needs to be thicker to have the same strength, delaying travel).

Timing is naturally variable but may be $\sim 1$ month earlier and occurrence more rapid.

Slush near the coastline is possibly more of an issue in recent years.

Ice-free season is $\sim 1$ month longer than in the past. Interviewees are doing more boating trips, boating earlier in spring and later in fall (mid-October in Cambridge Bay, midNovember in Kugluktuk).

Most interviewees did not notice changes. Several participants noted new cracks or zigzagging cracks (that used to be straight). A Kugluktuk hunter who used GPS to measure crack positions near Locker Point found that they have moved north over the past $\sim 30$ years by a few hundred metres. The number of pressure ridges may have increased over the past $10-15$ years (Kugluktuk). Pressure ridges used to be straight from Long Point to the mainland, but were recently observed to be perpendicular to their normal orientation. hunters thought SAR images and derived maps would be a beneficial educational tool for schools and for people who cannot observe the sea ice conditions directly, as they show information relevant to IK. Residents from both communities noted that the Canadian Rangers (subcomponent of the Canadian Armed Forces), Coast Guard, and search and rescue organizations would benefit from accessible, open access, SAR-based products, and other organizations that had already received RADARSAT-2 SAR images and training for navigation.
Most interviewees had no prior experience with SAR imagery. Before this study, restricted access RADARSAT-2 images were only made available once or twice a year in winter for planned Ranger excursions. The main use of the RADARSAT-2 images was to determine whether the sea ice was too rough for Rangers to undertake longer patrol trips (e.g., to distant early warning sites) and to help with route planning. CIS charts, which also show ice and open water conditions, were only used by one of the hunters interviewed from each of Kugluktuk and Cambridge Bay, 
TABLE 3. The traditional or current practices used to navigate sea ice conditions, and the information ideally desired by travelers. Features are described in Table 1 and the text.

\begin{tabular}{|c|c|c|}
\hline Feature & Traditional/current practices & Information desired \\
\hline $\begin{array}{l}\text { FYI (smooth/moderately rough/rough); } \\
\text { MYI; Snow on ice }\end{array}$ & $\begin{array}{l}\text { Look for high ground to see where the ice is smooth and } \\
\text { rough (weather and season-dependent). Try to travel as } \\
\text { straight as possible until rough ice is encountered. Follow } \\
\text { an existing trail (trails may be used throughout the sea ice } \\
\text { season by many people). }\end{array}$ & $\begin{array}{l}\text { Locations of each ice surface type, particularly for 1) } \\
\text { high-use areas, }{ }^{1} \text { 2) variable areas, }{ }^{2} \text { and } 3 \text { ) distant and less } \\
\text { frequently used areas. }\end{array}$ \\
\hline Thin ice & $\begin{array}{l}\text { Can recognize thin ice by the snow's profile (a subtle dent } \\
\text { in the snow) and knowledge of recent temperature and } \\
\text { weather conditions. }\end{array}$ & $\begin{array}{l}\text { Locations and timing of thin ice (or open water). Sea ice } \\
\text { thickness year-round. }\end{array}$ \\
\hline Early season ice & Test for thin ice. Look for open water. & $\begin{array}{l}\text { Locations of sea ice and open water. Sea ice thickness } \\
\text { and stage of development. Sea ice development over the } \\
\text { freeze-up period. }\end{array}$ \\
\hline Late season ice & Look at ice colour. Avoid areas known to melt early. & $\begin{array}{l}\text { Locations of sea ice and open water, especially as the ice } \\
\text { cover breaks and is an impediment to boating. On-ice } \\
\text { information needs change to boat and land needs. }\end{array}$ \\
\hline Slush or water on ice & $\begin{array}{l}\text { Reduce or avoid travel on the ice while melt ponds are } \\
\text { present. Travel next to cracks as adjacent areas are } \\
\text { dryer. }\end{array}$ & Locations of extensive slush or water on ice. \\
\hline Ice encountered by boats & $\begin{array}{l}\text { Check weather using online forecast, }{ }^{3} \text { VFR station (if } \\
\text { available), and marine forecast. Talk to people at outpost } \\
\text { camps about conditions. }\end{array}$ & $\begin{array}{l}\text { Ice location, movement, and type, from melt onset to } 90 \% \\
\text { ice-free ocean (spring) and from ice onset to complete } \\
\text { freeze-up (fall). Weather conditions. Icebreaker ship } \\
\text { presence and routes during the spring and fall. }\end{array}$ \\
\hline Ice discontinuities & $\begin{array}{l}\text { Mark discontinuity locations using GPS, wood sticks or } \\
\text { both. Share information about where cracks and pressure } \\
\text { ridges are traversable. }\end{array}$ & $\begin{array}{l}\text { Locations of ice discontinuities, especially in areas that } \\
\text { have many. }\end{array}$ \\
\hline
\end{tabular}

${ }^{1}$ E.g., between Victoria Island and the mainland.

${ }^{2}$ E.g., Dolphin and Union Strait, Hadley Bay, M'Clintock Channel.

${ }^{3}$ E.g., WindyTV (www.windy.com), Meteorologisk Institutt (www.yr.no), Environment and Climate Change Canada (https://weather. gc.ca), local weather stations linked to: https://people.ucalgary.ca/ belse/Brent_Else/WX.html

${ }^{4}$ Leads in Anderson Bay.

who orally disseminate related information to a limited number of others. When used, CIS charts were deemed mostly helpful for informing locations for spring boating.

Nearly all contributors indicated that the SAR-based maps are easy to understand when provided the image capture date, and they also expressed a desire for pairing sample SAR images with annotations and photographs as a way of providing context to make the imagery understandable. SAR image training was requested by each community and noted as helpful for 1) the complicated sea ice conditions during shoulder seasons (for the greyscale SAR-based maps) because images outside of winter were not familiar to anyone interviewed, and 2) anyone who has less IK with which to compare the images. Most interviewees thought that colour-coded images were more intuitive and would require less training to understand.

\section{Extent, Scale and Resolution}

SAR-based maps were at scales of $\sim 1: 400000$ to 1:800 000. Interviewees indicated that map extent, scale, and resolution should be tailored to show information of interest to individual communities. From Kugluktuk, most travel is within Coronation Gulf, though Amundsen Gulf was also identified as an area of interest. SAR-based maps provided to Cambridge Bay contained the main travel routes, including a route to the mainland via the more seasonally dangerous Finlayson Islands area. Small numbers of people travel long distances-from Kugluktuk to Cambridge Bay and beyond the NWT-Nunavut border, or from Cambridge Bay to M'Clintock Channel, Hadley Bay, Bathurst Inlet, King William Island, and Kugluktuk. Some people desire scale indicators in both metric distances and the more commonly used imperial equivalents.

The scale and spatial resolution of the SAR images used to make maps were deemed satisfactory and more helpful compared to the CIS weekly ice charts, particularly for roughness-related information for on-ice route planning and sea ice floe and open water locations in relation to spring boating. The large spatial coverage was also considered helpful, though interviewees expressed significant interest in information likely only available from higher-resolution, metre-scale SAR imagery, such as pressure ridges.

In terms of temporal resolution, interviewees want access to frequent SAR maps throughout the sea ice season, particularly during shoulder seasons, though needs 
TABLE 4. Evaluation of SAR-based maps in the context of their ability to provide safety and trafficability information about sea ice conditions and the potential benefits of the information provided. Features are described in Table 1 and the text. Information originates from interviews unless italicized.

\begin{tabular}{|c|c|c|}
\hline Feature & Evaluation of SAR & Benefits \\
\hline $\begin{array}{l}\text { FYI } \\
\text { (smooth/moderately rough/rough) }\end{array}$ & $\begin{array}{l}91 \% \text { of interviewees want winter SAR-based maps due to accurate } \\
\text { roughness observations. Existing travel routes mostly avoided rough areas. } \\
\text { Identify smooth ice areas and likely impassable areas. Winter greyscale } \\
\text { maps have easily interpretable tones, and are preferred by experienced } \\
\text { SAR users. Classified map categories correspond to local Inuinnaqtun } \\
\text { terminology. Classes may show more detail about roughness than greyscale } \\
\text { maps due to increased colour contrast and were preferred by interviewees } \\
\text { less experienced with SAR. Calm open water may be confused with smooth } \\
\text { FYI. }\end{array}$ & $\begin{array}{l}\text { Help plan safe and efficient routes. } \\
\text { Access roughness location information } \\
\text { for areas not yet traveled that season. } \\
\text { Accurately estimate or reduce trip } \\
\text { durations }{ }^{1} \text { (e.g., important when } \\
\text { traveling with small children). } \\
\text { Information for search and rescue } \\
\text { and ranger patrol operations. Good } \\
\text { educational resources. }\end{array}$ \\
\hline
\end{tabular}

MYI

Snow on ice

Thin ice

Early season ice

Late season ice

Slush or water on ice

Ice encountered by boats

Ice discontinuities
Identify areas of MYI on greyscale maps by bright tone and rounded floe texture. Regions with freshened ice (MYI/river outflow) are misclassified as rough.

Snow detection and its contributions to surface roughness are not shown and are not detectable using C-band SAR during winter.

Would like thin ice areas marked. Fine-scale data may be more helpful. Thickness is difficult to assess but can be inferred by ice type (coarse-scale).

Greyscale SAR is understood by experienced hunters and provides useful information about sea ice cover/evolution. Can observe wind direction, high current areas (influence on ice), locations where ice accumulates, ice qualities, and areas of open water. More difficult to read than winter images, but are helpful as conditions are unknown. Usually more important than spring images. Rapid sea ice changes mean images may be outdated but most people would still check them. May be able to extrapolate subsequent ice conditions using knowledge of weather and the environment.

As in early season ice, except conditions more known from travel throughout the season. SAR is interpreted for the appropriate transportation mode.

Interviewees showed interest in SAR and other imagery showing melt pond distributions, but fine-scale information is needed to provide travel information. Surface fraction covered by melt ponds can be detected (and predicted using winter imagery). Slush detection is not directly possible through SAR-based maps. Polarimetric analysis is untested but may prove useful: $H H / V V$ ratio data is linked to moisture/dielectric permittivity.

Detection of sea ice and open water is possible. Images show ice congestion along travel routes, and whether ice is present that may move and block travel. Can detect when areas become boat accessible. ${ }^{2}$ Ship detection is possible.

Nearly all discontinuities are too small to be seen on Sentinel-1 EW/ RADARSAT-2 ScanSAR Wide images. Pressure ridges and leads are sometimes visible. Detection of smaller features may be achieved using finer-scale or higher-frequency SAR data.
Identification helps when planning safe and efficient routes. May be a destination.

Would be useful to understand the snow contribution to surface roughness.

Would be educational resources. Detection of new areas could help prevent accidents.

Help people assess where and when to travel. Provide access to sea ice evolution information before and as ice becomes trafficable. Give spatial information about sea ice, open water, and wind.

Help people assess when and where to travel. Provide spatial information about sea ice, open water, and wind during a highly dynamic period.

Help people plan routes that avoid onice water and slush.

Can assess when and where routes avoid sea ice. Help people prepare for larger ocean swells when sea ice is absent. Shows whether icebreaker ships have cleared ice for boating (spring) or broken the ice and made it dangerous for snowmobiles (fall).

Would be useful for safety and navigation. Location information is especially helpful for people who still need to learn approximate ice discontinuity locations. Discontinuity detection could help prevent accidents.

${ }^{1}$ In 2017, it was possible to save $\sim 5$ hours when travelling between Jenny Lind Island and Cambridge Bay $(\sim 20 \mathrm{~km})$.

${ }^{2}$ E.g., for people who snowmobile to camps and boat back to Kugluktuk or leave Cambridge Bay and boat to the mainland.

vary depending on the location of interest. For example, in M'Clintock Channel and Victoria Strait, the sea ice is known to move until mid-January, well after ice near the communities is thick and landfast. Ideally, greyscale SARbased maps would show current conditions during freeze-up and breakup, but the 2-4 day revisit frequency of Sentinel-1, at this latitude and under the current predetermined observation scenario, means that images may be several days old (ESA, 2018b). Outdated images were not considered obsolete; they are considered useful for understanding ice 


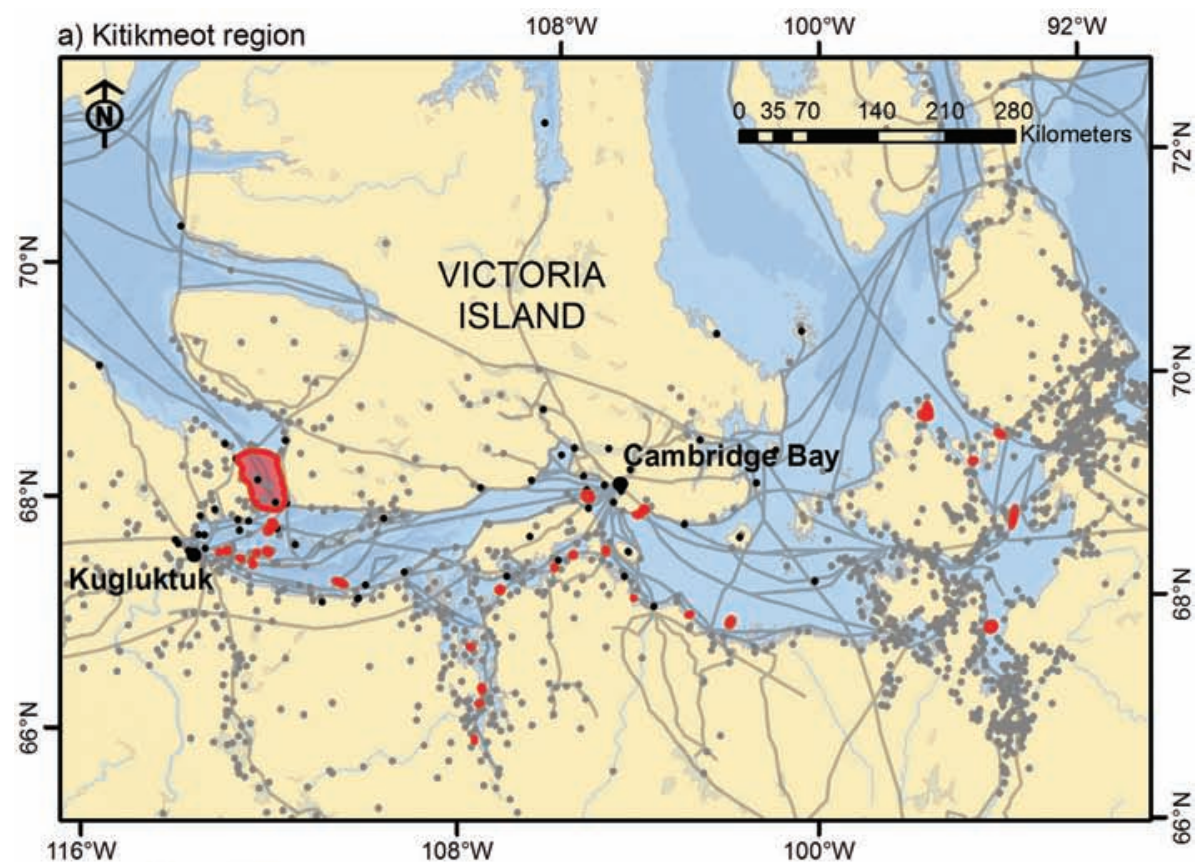

b) Kugluktuk region
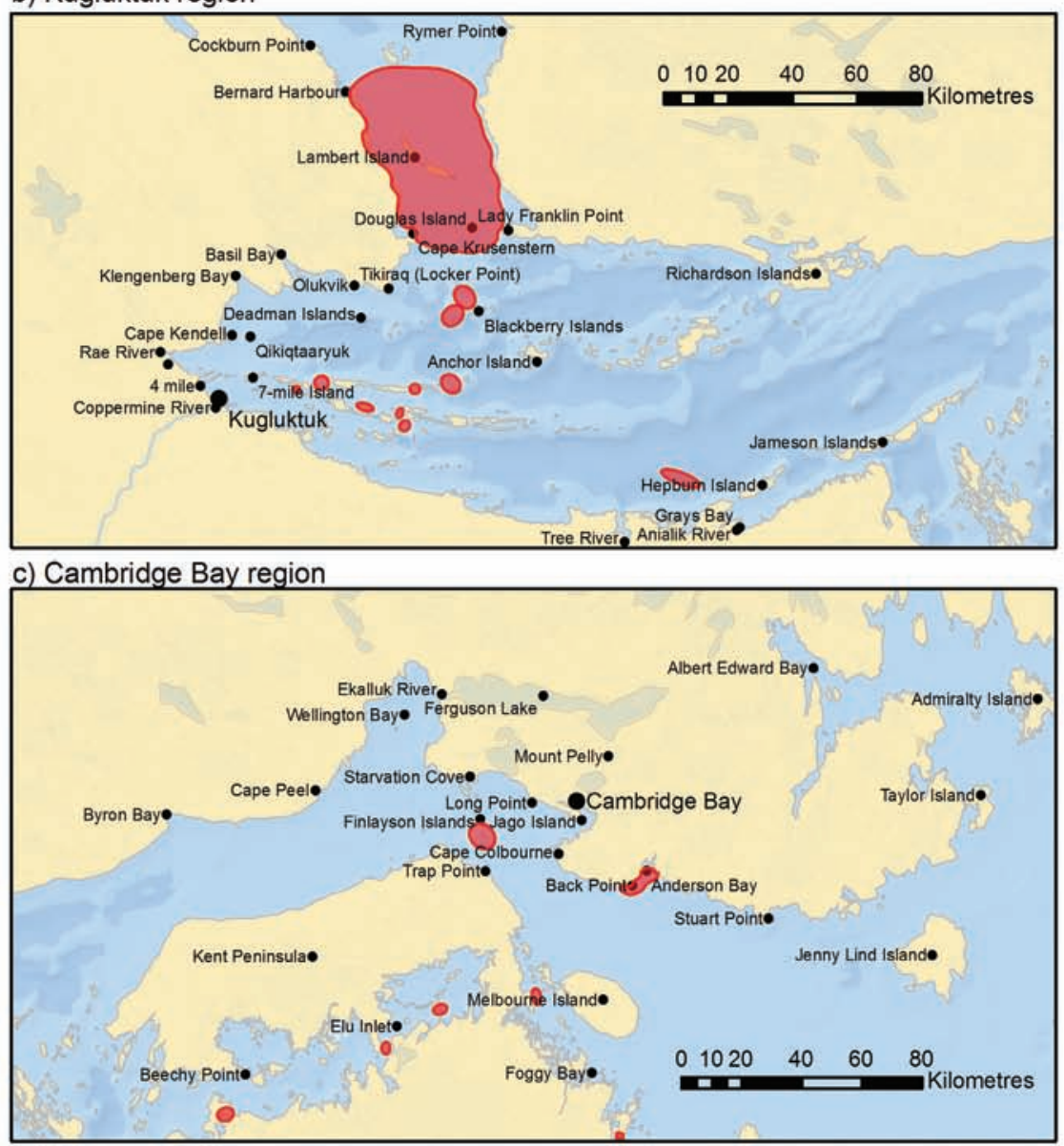

Danger: thin sea ice or open water

FIG. 3. Maps showing sea ice use and locations of thin sea ice identified by local experts as dangerous seasonally or year-round. Important places mentioned in interviews are displayed as black dots, and dangerous areas are displayed as red polygons, across the a) Kitikmeot, b) Kugluktuk, and c) Cambridge Bay regions. Map a) also shows the main travel routes (grey lines) and important places (grey dots) identified by the Inuit Heritage Trust (http:/ihti.ca/eng/iht-proj-plac.html) and gives a more complete picture of the extent of travel and where information is useful. The maps do not show a comprehensive list of dangerous areas; several contributors discussed knowing that more thin ice areas existed but they could not pinpoint their exact locations. Dangerous areas closer to other communities would be better known by their residents, and other areas may appear with climate change. 
evolution in the context of recent weather conditions and as a sequence denoting ice condition evolution. For example, rapid changes between images may indicate more hazardous conditions. One Kugluktuk hunter's interpretation of the conditions during fall and winter are described in the supplementary file. Generally, hunters were most interested in evaluating SAR-based maps using base imagery that is either current or within the last $\sim$ two years. Contributors from both communities would like historical and future imagery to be compiled over time to see how sea ice evolves annually and to identify patterns and discrepancies, such as in the freeze-up period or ice roughness.

\section{Access and Expectation Management}

Local residents expressed a desire for greyscale and colour-coded SAR-based maps to be accessible in printed and digital formats, as they expect them to be checked like weather reports before excursions. Preferred formats include large print maps, take-home printouts, books containing sequential images, local television coverage, or online digital images. Printed maps are important for people without Internet access and are considered most potentially impactful if regularly updated and located centrally (e.g., at the HTO, wildlife office or library). Most contributors want maps to take on the ice or offline versions on mobile devices. It was noted that since the Internet makes downloading large files problematic, online digital maps must be available on low bandwidth platforms that are preferably user-friendly and interactive. Several interviewees suggested posting maps on Facebook since it is a widely used method of communication; we subsequently posted Facebook updates in fall 2018 and in the winter and spring of 2019-20 that were well-received. A few interviewees suggested making the SAR-based maps available on a government website or partnered with existing weather information.

During the first field season, we came to understand that SAR-based maps were highly desired in both communities, but we did not have a viable way of giving people access to these maps aside from leaving behind printed maps. We made considerable efforts to manage community expectations about the project's outcomes by emphasizing that the research team had limited capacity to create new infrastructure. Instead, we would advocate for community interests through groups with existing infrastructure, but we noted that progress was not guaranteed and would take considerable time. Instead of setting up an official channel for delivering SAR-based maps, we offered to make and share digital maps upon request and through Facebook. Requests for new SAR-based maps or maps of different areas were received by phone, email, and Facebook throughout this study, with the most requests occurring in early spring (February and March, typically for long distance travel) and fall. We have also observed sharing by others on Facebook, including screenshots of features impacting safety and travel (e.g., leads, rough ice).
Technological capacity (satellite data availability and processing capacity), however, has grown. During the later field seasons, we were able to talk about the increasing progress made towards online digital SAR-based map availability, display maps made in Google Earth Engine, and discuss plans to make the data available automatically through SIKU. SIKU (2020) is a web platform hosted by the non-profit organization Arctic Eider Society. Developed by and for Inuit, the platform hosts satellite imagery from a variety of freely available sensors including Sentinel-1.

\section{DISCUSSION}

\section{SAR-based Roughness Maps}

Our initial interviews revealed that delineating areas based on the degree of sea ice roughness using SAR would be beneficial for both communities. Consequently, colourcoded, SAR-based roughness maps (Fig. 4) for winter were created by thresholding backscatter values to delineate three classes representing "smooth," "moderately rough," and "rough" roughness domains, displayed as green, yellow, and purple, respectively. In the local Inuinnaqtun language these categories are maniqtuk hiku (smooth ice), maniilrulik hiku (moderately rough ice), and maniittuq hiku (rough ice). The prevalence of the English words "smooth," "sort of rough," and "rough," in interviews along with the matching Inuinnaqtun words further indicates that the SAR categories are of local importance. Colour-coded SARbased maps were also used to generate specific discussion points, such as identifying areas that are consistently smooth or rough on an interannual basis. Suggestions for improvement were also recorded. A few interviewees noted that riverine output areas (e.g., the Coppermine River mouth) were commonly misclassified. Hazardous thin ice areas were requested as map overlays, and map colours were changed to convey less alarming navigation suggestions (Fig. 5).

Thresholds were initially determined by manual selection, based on results showing a linear relationship between C-band SAR backscatter intensity and root mean square sea ice surface roughness for FYI in the CAA (Cafarella et al., 2019; Segal et al., 2020). Domains were color-coded into classes representing sea ice snowmobile travel that is 1) easy (teal; $<-20 \mathrm{~dB}$ ), 2) slow but passable with caution (orange; $\geq-20$ and $\leq-18 \mathrm{~dB}$ ), and 3 ) impassable or takes considerable effort (red; $>-18 \mathrm{~dB}$ ). Thresholds were applied to the Sentinel-1 images after preprocessing (see Methods). We expected that refinement and validation based on community input and quantitative analyses might occur.

By the third field season, we also created SAR-based maps using Google Earth Engine (Gorelick et al., 2017). Online processing is advantageous because the Sentinel-1 images are hosted by Google, so the images can be thresholded into roughness classes using a near-real time 


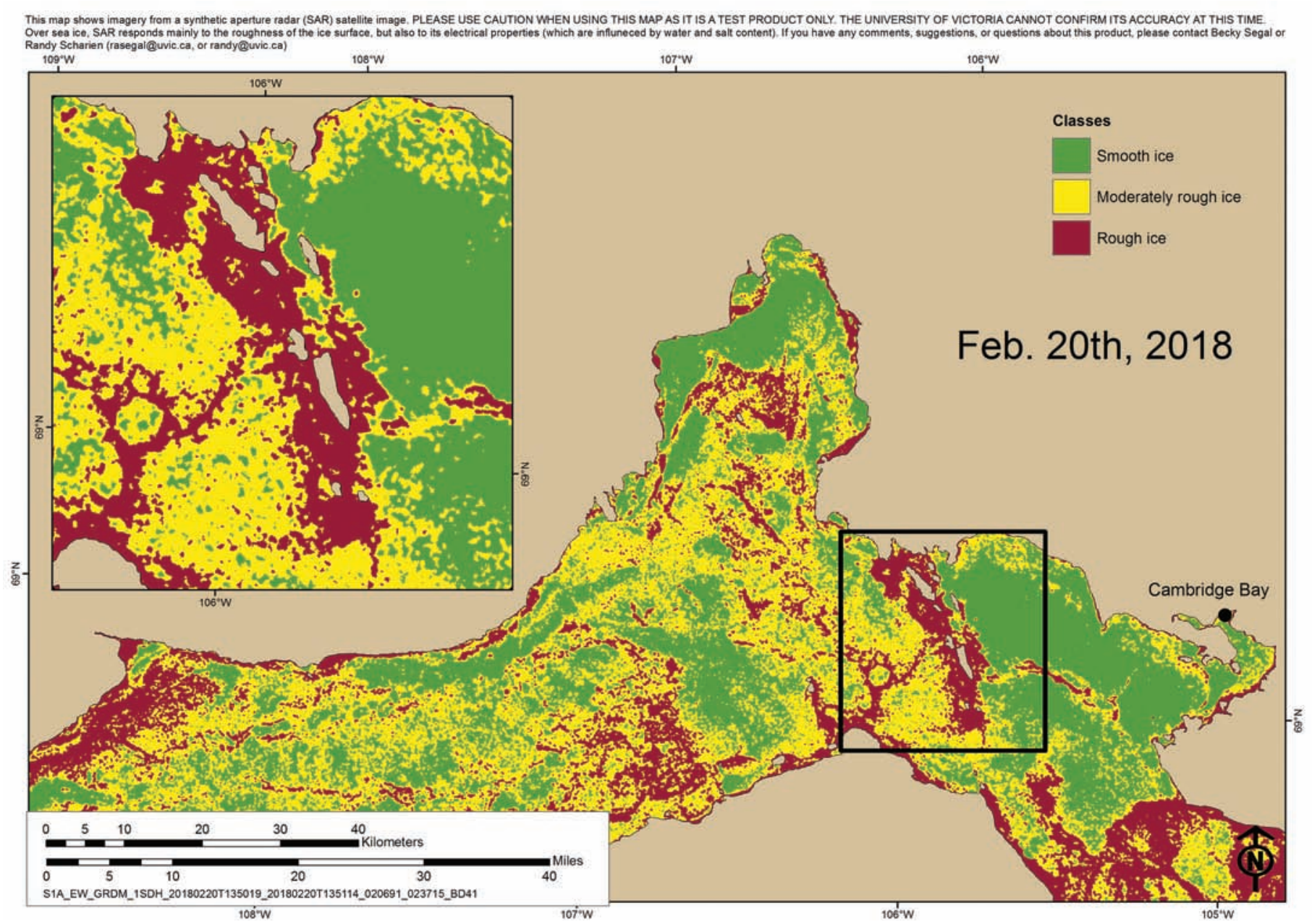

FIG. 4. Example of a Sentinel-1-based map of sea ice roughness that was brought to Cambridge Bay. The map is colour-coded to show the degree of sea ice roughness (smooth ice, moderately rough ice, and rough ice).

processing chain. Digital maps became available on the SIKU platform (siku.org) beginning in December 2018. SIKU also provides information on weather and tides, social-media-style user observations, as well as educational materials. To improve speed for bandwidth-limited users, the maps are displayed on demand for the portion of the map view that the user requests as a collection of tiles. As the sea ice evolves, users may pan to areas of interest, look at historical imagery, and mark hazardous or otherwise notable areas. Furthermore, the SIKU platform allows users to tag photos and details of sea ice observations, which can be viewed as a layer displayed over supported satellite products. These layers may assist user interpretation of SAR imagery and could potentially be used as groundtruth data for SAR-based map improvements. However, the SIKU platform requires users to create a personal login; while there is no financial charge, this is a barrier to some users.

In the future, the colour-coded SAR-based maps could be improved by adding classes for known dangerous areas (thin ice or open water; Fig. 3) and for freshened ice (river output and MYI areas) because these areas decorrelate from roughness (Segal et al., 2020), as well as for ice that is not landfast. Ideally, this extra information could be integrated into one layer and available at a similar spatiotemporal scale as the SAR images. Further refinement of the thresholding technique or modelling of roughness from backscatter for this region and other areas is required. The utility of mapping ice roughness also needs to be assessed for different communities and cultural contexts.

\section{Other Technology and Applications}

Overall, there was an overwhelmingly positive response to the SAR-based maps and a desire to understand and have access to other technologies that can supplement IK, aid the understanding of features in Table 1, and include land and larger lake conditions. Desired lake data include freeze-up and melt progression, as well as ice thickness and roughness.

Optical satellite imagery was also desired by sea ice travelers because colours in the optical spectrum reveal conditions like those observed by the eye (e.g., thick FYI vs. grey ice). While optical imagery is easier to interpret than SAR backscatter, acquisitions are inhibited by cloud cover and darkness. However, on bright, clear days, optical 


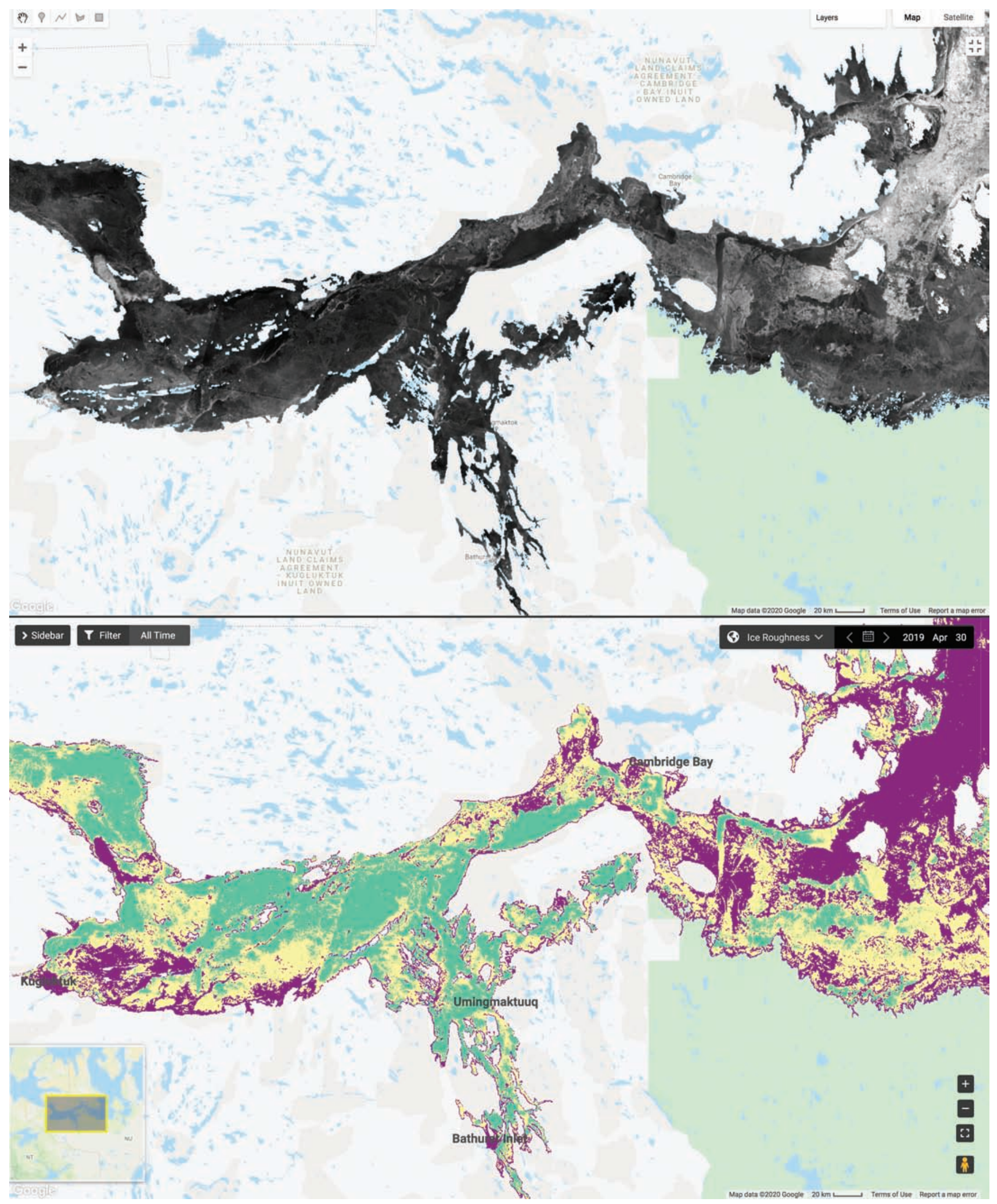

FIG. 5. Top: Greyscale Sentinel-1 SAR-based map of April 2019 images on the Google Earth Engine platform. Bottom: Colour-coded roughness map viewed on the SIKU website (siku.org) using the selected date of 30 April 2019. Green: maniktuq hiku (smooth ice), yellow: maniilrulik hiku (moderately rough ice), and purple: maniittuq hiku (rough ice). 
images are able to show ice-water colour contrasts clearly; Sentinel-2 images brought to the communities were wellreceived because they showed areas that melted out early. Several interviewees from Kugluktuk already use coarse spatial resolution optical satellite imagery from online platforms like NASA Worldview to see open water areas and infer sea ice thickness from colour. Furthermore, it may be possible to derive snow surface roughness using multiangle optical data (Segal et al., 2020). For a list of radar, optical, and other satellite sensors that may provide useful information in the community context, see Segal et al. (2020).

Sea ice thickness data are desired by sea ice users because the data are highly important for safe navigation. Interest is compounded by noted changes in breakup and freeze-up timing patterns and the development of new areas of thin sea ice at unexpected times. Ice profilers can measure ice thickness using either electromagnetic induction (electric conductivity) or by radio echo sounding (ground-penetrating radar), which calculates the return time of an electromagnetic pulse reflecting from the sea ice bottom surface (Haas and Druckenmiller, 2009; Dammann et al., 2018a). Several Cambridge Bay residents noted that ice profilers towed on a sled over sea ice would be valuable for scientific or industrial projects that require towing equipment heavier than snowmobiles if they are suitable for snow-covered sea ice measurements (Druckenmiller et al., 2013). Mass-balance buoys frozen in the sea ice also provide ice and water temperatures and ice thickness information (Richter-Menge et al., 2006; Druckenmiller et al., 2013). Kugluktuk residents are uncertain whether massbalance buoys would provide helpful information, because thickness varies with the currents. Despite this limitation, contributors from both communities were interested in accessing ice profiler and mass-balance buoy-derived thickness data.

\section{Comparison to Other Research}

A study of sea ice and weather in Kugluktuk and Cambridge Bay was conducted by Panikkar et al. (2018), in which local residents noted similar trafficability concerns and changes. Like this study, they found that 1) IK is not being transferred to younger generations, leading to unsafe travel by inexperienced people, 2) technology is helpful and largely desirable but should be used with caution, 3) information about sea ice roughness and weather conditions is desired, and 4) people generally know the locations and timings of dangerous thin ice. Some interviewees, mostly from Kugluktuk, discussed the potentially prohibitive expenses associated with travel, particularly in rough ice areas. Panikkar et al. (2018) also recorded observations of environmental changes, including later freeze-up and (possibly) earlier breakup; probable changes in storms, snowfall, and prevailing winds, which affect snowdrift formation; new patterns in pressure ridge and lead locations; and increased underwater sediment deposits.
These separately obtained conclusions indicate that there are strong and consistent observations of change and information desires in Kugluktuk and Cambridge Bay. In contrast, Ford et al. (2019) found that ice trail access in Canadian Inuit communities decreased by up to two days from 1985 to 2016 because of environmental changes. This decrease is lower than the approximations of one month of decreased access observed by the interviewees in our studied communities.

Numerous studies from other Arctic regions mention sea ice roughness as a condition impacting sea ice travel or as an information need or both (Aporta, 2004; Laidler et al., 2011; Druckenmiller et al., 2013; Bell et al., 2014; Dammann et al., 2018b; Panikkar et al., 2018; Segal, 2019). There is consensus between Dammann et al. (2018b), Druckenmiller et al. (2013), and this study, which all found that roughness at scales of $\sim 0.1-10 \mathrm{~m}$ is important for trafficability. Trends towards rougher sea ice are observed by respondents in our study, as well as by Dammann et al. (2018b), who suggest that ice roughness may increase in the Arctic because ice is forming later than normal (during the storm season), experiencing more strain, fracturing, and storms, as well as moving at increased speeds. Consequently, data about sea ice trafficability like SAR-based maps may prove increasingly valuable in the future.

The floe edge (Inuinnaqtun: Hikum hinaa) is defined in this study as where an ice floe or landfast ice abuts either moving ice or water. Unlike many other communities, knowledge of floe edge positions is not a priority for Kugluktuk and Cambridge Bay residents. Information on floe edges is critical in areas where there is an ice edge that can fracture unexpectedly and drift away (Laidler et al., 2011; Kim et al., 2015; Dammann, 2017; Dammann et al., 2018a, 2019; Deemer et al., 2018). There is currently no winter floe edge near Kugluktuk or Cambridge Bay, although a few hunters proposed that floe edges may emerge due to climate change. Several interviewees recognized that their landfast ice is more stable and predictable than in the eastern Canadian Arctic, meaning that the sea ice will not break off and begin moving in winter. Some contributors from Kugluktuk noted that currently there is no reason (e.g., whale presence) to exert the energy to travel the distance to the floe edge. One hunter discussed a floe edge feature north of Kugluktuk, from Clifton Point across Dolphin and Union Strait to Ulukhaktok (see Fig. 1), an area that is a destination for polar bear hunts. The stabilitylinked concerns identified by Dammann et al. (2018a) were the only concerns that were not described by the hunters interviewed in this study.

\section{Impact of Information on Trafficability}

Like Ford et al. (2019), we found that the inability to tolerate travel hazards significantly impacts trail access; an experienced traveler has considerably more access to ice trails than a traveler who can only tolerate low-hazard situations. Trails typically follow smooth ice, detour 
around rough and thin ice areas, and are modified when it is recognized that they can be improved or when ice conditions change. However, Kugluktuk and Cambridge Bay travelers discussed integrating information from SAR-based maps into a broader decision-making process regarding trail selection. Druckenmiller et al. (2013) report that, while trail selection is impacted by safety and experience, it is also influenced by access to destinations, availability of preferred ice types (e.g., desired floe edge characteristics), convenience (e.g., amount of work to make a trail), and tradition (e.g., routes, destinations). We also found that travelers discussed important destinations and traditional areas (e.g., camps, routes that are made each year), as well as important ice types and convenience (e.g., for travel ease, animal access, and emergency shelter). Like Aporta (2004), we heard that using known trails, which are considered places in and of themselves, has the added benefit of improving safety because it is easier to get help. Trails are typically set by experienced travellers and followed by the increasing numbers of less experienced "track followers" (also noted in Aporta, 2004). As a result of these socially determined factors, the least-cost path identified on a SAR-map may not be chosen as a travel route. However, sometimes the SAR-based maps serve as discussion points for hunters and have a large impact on route selection, and not always through depicting trafficability. Several hunters relayed that they are able to use the classified SAR-based maps to identify and match sea ice surface roughness to the wildlife they want to hunt, using their IK.

\section{CONCLUSIONS}

Changes in the Kugluktuk and Cambridge Bay communities and their surrounding environments are impacting sea ice use and creating uncertainty regarding trafficable conditions. SAR-based maps are a welcome information supplement that complements IK by providing high spatiotemporal resolution images of sea ice features and seasonal conditions that aid in informing and improving sea ice safety, trafficability, and education.

The sea ice conditions that impact trafficability and safety in Kugluktuk and Cambridge Bay are defined by local residents as smooth, moderately rough, and rough sea ice, MYI, snow on ice, thin ice, early ice, late ice, slush or water on ice, ice encountered by boats, and ice discontinuities. Sea ice surface roughness is considered the main ice condition where benefits to trafficability from SAR-based mapping are regarded as substantial. Both greyscale and colour-coded Sentinel-1 SAR-based maps of sea ice surface roughness show good agreement with local understanding and observations, except in areas of freshened ice influence (i.e., MYI and riverine output areas) or heavy snow. Colour-coded SAR-based maps showing the degree of sea ice roughness are desired throughout the sea ice season, particularly in fall and winter. Winter Sentinel-1 images can be used to quantitatively map sea ice roughness, whereas images acquired during spring and fall conditions are affected by freeze-up and melting conditions and are more difficult to assess. In addition to winter surface roughness, derived maps should contain ancillary danger warnings depicting areas generally known to contain thin ice, along with a written warning that thin ice is not captured by the SAR images used to create them. Areas prone to thin sea ice, even in winter, could be identified by local knowledge holders since satellite remote sensing cannot currently provide ice thickness information at the spatial and temporal resolutions necessary for informing trafficability. Dissemination in both digital and printed, greyscale and colour-coded, SAR-based maps would be beneficial for broadening their use in communities.

We highly recommend that agencies providing sea ice information to communities should consider enabling access to higher-resolution imagery, either free or otherwise affordable, as higher resolution modes are within the current technological capabilities of existing sensors, including Sentinel-1, RADARSAT-2, and RCM. While the methods developed in this study would need to be tested and possibly recalibrated for other SAR sensors, they are likely transferrable to other C-band sensors because of the similarity of the sensors. Other frequencies, polarisations, modes, and incidence angles may need to be interpreted differently.

Community members would also benefit from the increased temporal frequency offered by the addition of information from other sensors that are already collecting (restricted) images, like RCM and RADARSAT-2 (and possibly SARs using other frequencies), with greater benefits in the shoulder seasons. While it is difficult to assess the exact frequency that is helpful, since interviewees have had limited opportunities to test the benefits of frequent access, they suggest that higher temporal frequency is better because conditions can change rapidly (within hours) in the fall and spring.

Sentinel-1 SAR imagery and derived maps were used in this study because the imagery is readily accessible and translation of backscatter to a surface roughness proxy is relatively straightforward. Previous research has pointed to the utility of more advanced SAR techniques, such as radar polarimetry and SAR interferometry (InSAR), for assessing ice conditions such as roughness and hazards (see Introduction). A polarimetric SAR, such as RADARAT-2, provides enhanced scattering information content for target identification by enabling backscatter data from all transmit and receive polarization combinations to be synthesized from a single collection. Polarimetric data may be useful for discriminating features on the basis of their orientations or primary scattering mechanisms (e.g., volume scattering fresh ice) rather than backscatter intensity, as well as for identifying important features related to melt or freeze-up. InSAR, a technique that measures changes in signal phase between acquisitions offset in space or time, can be used to detect topographic height or motion-related displacement, 
respectively. These techniques require further investigation in the context of safe sea ice use in the Canadian Arctic Archipelago and elsewhere.

Nearly everyone interviewed thought that offering in-person training workshops in their community about the basics of SAR sensors, interpretation, and product access would be effective. As well, several of the hunters interviewed in this study were passionate about the need for younger people to learn more about sea ice. Education, training, and supplementary technological tools used for navigation and education could therefore enhance access to sea ice. SAR-based maps provide benefits for education - they allow easy access to sea ice information and can act as discussion foci. For wider sharing of SARbased maps, regional differences in sea ice conditions must be considered in the context of community information priorities.

\section{ACKNOWLEDGEMENTS}

We gratefully acknowledge the hospitality, assistance, and expertise of the residents and partnered organizations in both Kugluktuk and Cambridge Bay. We thank the hunters and elders who shared wisdom during interviews and sea ice excursions, Jessica MacLean for assistance with interview transcription, Trilby Buck for support in the field, as well as Andy Wynden and Sasha Nasonova for programming support. We also acknowledge Mary Kaosoni, who looked over a preprint and translated the Inuinnaqtun ice terms and abstract, and Sasha Nasonova, Grigori Nasonov, and Svetlana Lopareva who provided a Russian abstract. The title "the best of both worlds" is part of a quote from our interview with Amanda Dumond (from Kugluktuk) and is used with her permission. We acknowledge a beneficial partnership with Ocean Networks Canada and the University of Victoria's Climate Lab. We would also like to thank three reviewers who provided insightful feedback that greatly improved the manuscript. This research was supported by the Marine Environmental Observation Prediction and Response network and Irving Shipbuilding Inc. project number 1.22, Polar Knowledge Canada (NST-1718-0024), the W. Garfield Weston Foundation through the Association of Canadian Universities for Northern Studies, the Natural Sciences and Engineering Research Council of Canada, the Royal Canadian Geographical Society, the Arctic Institute of North America, and the University of Victoria. Sentinel-1 data are freely provided by the European Space Agency. Interviews comply with the Human Research Ethics Board at the University of Victoria (protocol 17-130) as well as Nunavut Research Institute licenses 04008 17R-M, 04 010 18R-M, and 04008 18R-M.

\section{REFERENCES}

ACIA (Arctic Climate Impact Assessment). 2005. Arctic climate impact assessment: Scientific report. New York: Cambridge University Press.

www.cambridge.org/9780521865098
AMAP (Arctic Monitoring and Assessment Programme). 2011. Snow, water, ice and permafrost in the Arctic (SWIPA): Climate change and the cryosphere. Oslo, Norway: AMAP. https://www.amap.no/documents/doc/snow-water-ice-andpermafrost-in-the-arctic-swipa-climate-change-and-thecryosphere/743

Aporta, C. 2004. Routes, trails and tracks: Trail breaking among the Inuit of Igloolik. Études/Inuit/Studies 28(2):9-38. https://doi.org/10.7202/013194ar

—_ _ 2009. The trail as home: Inuit and their pan-Arctic network of routes. Human Ecology 37(2):131- 146. https://doi.org/10.1007/s10745-009-9213-x

Bekryaev, R.V., Polyakov, I.V., and Alexeev, V.A. 2010. Role of polar amplification in long-term surface air temperature variations and modern Arctic warming. Journal of Climate 23(14):3888-3906. https://doi.org/10.1175/2010JCLI3297.1

Bell, T., Briggs, R., Bachmayer, R., and Li, S. 2014. Augmenting Inuit knowledge for safe sea-ice travel - The SmartICE information system. Presented at 2014 Oceans - St. John's, 14-19 September 2014, St. John's, Newfoundland. 9 p.

https://doi.org/10.1109/OCEANS.2014.7003290

Bertoia, C., Falkingham, J., and Fetterer, F. 1998. Polar SAR data for operational sea ice mapping. In: Tsatsoulis, C., and Kwok, R., eds. Analysis of SAR data of the polar oceans. Berlin and Heidelberg: Springer. 201-234. https://doi.org/10.1007/978-3-642-60282-5_10

Bhatt, U.S., Walker, D.A., Raynolds, M.K., Comiso, J.C., Epstein, H.E., Jia, G., Gens, R., et al. 2010. Circumpolar Arctic tundra vegetation change is linked to sea ice decline. Earth Interactions 14(8):1-20. https://doi.org/10.1175/2010EI315.1

Brinton, M. 2018. Risk and uncertainty regarding Inuit transportation in the face of climate change. MA thesis, Boise State University, Boise, Idaho.

https://scholarworks.boisestate.edu/cgi/viewcontent.cgi? article $=2522 \&$ context $=\mathrm{td}$

Bush, E., and Lemmen, D.S., eds. 2019. Canada's changing climate report. Ottawa, Ontario: Government of Canada. 444 p. http://publications.gc.ca/collections/collection_2019/eccc/ En4-368-2019-eng.pdf

Cafarella, S.M., Scharien, R., Geldsetzer, T., Howell, S., Haas, C., Segal, R., and Nasonova, S. 2019. Estimation of level and deformed first-year sea ice surface roughness in the Canadian Arctic Archipelago from C- and L-band synthetic aperture radar. Canadian Journal of Remote Sensing 45(3-4):457-475. https://doi.org/10.1080/07038992.2019.1647102

Calihoo, C., and Romaine, T. 2010. Climate change adaptation action plan for Cambridge Bay. Cambridge Bay, Nunavut: Municipal Corporation of Cambridge Bay. https://www.cip-icu.ca/Files/Resources/CAMBRIDGEBAY_ CCAP_E

Chan, Y.K., and Koo, V.C. 2008. An introduction to synthetic aperture radar (SAR). Progress in Electromagnetics Research B 2:27-60.

https://doi.org/10.2528/PIERB07110101 
CIS (Canadian Ice Service). 2011. Sea ice climatic atlas for the northern Canadian waters 1981 -2010. Ottawa, Ontario: CIS.

Clark, Do.G., Ford, J.D., Berrang-Ford, L., Pearce, T., Kowal, S., and Gough, W.A. 2016. The role of environmental factors in search and rescue incidents in Nunavut, Canada. Public Health 137:44-49. https://doi.org/10.1016/j.puhe.2016.06.003

Clark, Dy.G., Ford, J.D., Pearce, T., and Berrang-Ford, L. 2016. Vulnerability to unintentional injuries associated with landuse activities and search and rescue in Nunavut, Canada. Social Science \& Medicine 169:18-26. https://doi.org/10.1016/j.socscimed.2016.09.026

Comiso, J.C., and Hall, D.K. 2014. Climate trends in the Arctic as observed from space. Wiley Interdisciplinary Reviews: WIREs Climate Change 5(3):389-409. https://doi.org/10.1002/wcc. 277

Dammann, D.O. 2017. Arctic sea ice trafficability - New strategies for a changing icescape. PhD thesis, University of Alaska Fairbanks, Fairbanks, Alaska. https://search.proquest.com/docview/1916037079/abstract/ 447EFD1B917248E9PQ/1

Dammann, D.O., Eicken, H., Mahoney, A.R., Meyer, F.J., and Betcher, S. 2018a. Assessing sea ice trafficability in a changing Arctic. Arctic 71(1):59-75. https://doi.org/10.14430/arctic4701

Dammann, D.O., Eicken, H., Mahoney, A.R., Saiet, E., Meyer, F.J., and George, J.C. 2018b. Traversing sea ice: Linking surface roughness and ice trafficability through SAR polarimetry and interferometry. IEEE Journal of Selected Topics in Applied Earth Observations and Remote Sensing 11(2):416-433. https://doi.org/10.1109/JSTARS.2017.2764961

Dammann, D.O., Eriksson, L.E.B., Mahoney, A.R., Eicken, H., and Meyer, F.J. 2019. Mapping pan-Arctic landfast sea ice stability using Sentinel-1 interferometry. The Cryosphere 13(2):557-577. https://doi.org/10.5194/tc-13-557-2019

Dawson, J., Hoke, W., Lamers, M., Liggett, D., Ljubicic, G., Mills, B., Stewart, E., and Thoman, R. 2017. Navigating weather, water, ice and climate information for safe polar mobilities. WWRP-PPP No. 5. Polar Prediction Project - Societal and Economic Research and Applications Working Group. Geneva, Switzerland: World Meteorological Organization.

https://www.polarprediction.net/fileadmin/user_upload/www. polarprediction.net/Home/Organization/Task_Teams/PPPSERA/WWRP_PPP_No_5_2017_11_OCT.pdf

Deemer, G.J., Bhatt, U.S., Eicken, H., Posey, P.G., Hutchings, J.K., Nelson, J., Heim, R., Allard, R.A., Wiggins, H., and Creek, K. 2018. Broadening the sea-ice forecaster toolbox with community observations: A case study from the northern Bering Sea. Arctic Science 4:42-70. https://doi.org/10.1139/AS-2016-0054

Dierking, W. 2013. Sea ice monitoring by synthetic aperture radar. Oceanography 26(2):100-111. https://doi.org/10.5670/oceanog.2013.33
Dowsley, M., Gearheard, S., Johnson, N., and Inksetter, J. 2010. Should we turn the tent? Inuit women and climate change. Études/Inuit/Studies 34(1):151-165. https://doi.org/10.7202/045409ar

Druckenmiller, M.L., Eicken, H., Johnson, M.A., Pringle, D.J., and Williams, C.C. 2009. Toward an integrated coastal sea-ice observatory: System components and a case study at Barrow, Alaska. Cold Regions Science and Technology 56(2-3):61-72. https://doi.org/10.1016/j.coldregions.2008.12.003

Druckenmiller, M.L., Eicken, H., George, J.C., and Brower, L. 2013. Trails to the whale: Reflections of change and choice on an Iñupiat icescape at Barrow, Alaska. Polar Geography 36(12):5-29. https://doi.org/10.1080/1088937X.2012.724459

Eicken, H., and Mahoney, A.R. 2015. Chapter 13 - Sea ice: Hazards, risks, and implications for disasters. In: Ellis, J.T., and Sherman, D.J., eds. Coastal and marine hazards, risks, and disasters. Boston: Elsevier. 381-401. https://doi.org/10.1016/B978-0-12-396483-0.00013-3

Eicken, H., Jones, J., Meyer, F., Mahoney, A., Druckenmiller, M.L., Rohith, M.V., and Kambhamettu, C. 2011. Environmental security in Arctic ice-covered seas: From strategy to tactics of hazard identification and emergency response. Marine Technology Society Journal 45(3):37-48. https://doi.org/10.4031/MTSJ.45.3.1

Ersahin, K., Brown, L., Kanwar, A., Henley, M., Ross, E., and Fissel, D. 2014. Characterization of hazardous ice using spaceborne SAR and ice profiling sonar: Preliminary results. Offshore Technology Conference, 10-12 February 2014, Houston, Texas. https://doi.org/10.4043/24600-MS

ESA (European Space Agency). 2018a. Sentinel-1 SAR User guide introduction. ESA Sentinel Online.

https://sentinel.esa.int/web/sentinel/user-guides/sentinel-1-sar

___ 2018b. Sentinel-1 observation scenario archive. ESA Sentinel Online.

https://sentinel.esa.int/web/sentinel/missions/sentinel-1/ observation-scenario

Fisheries and Oceans Canada. 2012. Ice climatology and environmental conditions. Ice Navigation in Canadian Waters. Ottawa, Ontario: Icebreaking Program, Maritime Services, Canadian Coast Guard, Fisheries and Oceans Canada. 32-78. https://www.ccg-gcc.gc.ca/publications/icebreakingdeglacage/ice-navigation-glaces/docs/ice-navigation-dans-lesgalces-eng.pdf

Ford, J.D. 2005. Living with climate change in the Arctic. Worldwatch Institute 18(5):18-21.

Ford, J.D., and Smit, B. 2004. A framework for assessing the vulnerability of communities in the Canadian Arctic to risks associated with climate change. Arctic 57(4):389-400. https://doi.org/10.14430/arctic516

Ford, J.D., Smit, B., and Wandel, J. 2006a. Vulnerability to climate change in the Arctic: A case study from Arctic Bay, Canada. Global Environmental Change 16(2):145-160. https://doi.org/10.1016/j.gloenvcha.2005.11.007 
Ford, J.D., Smit, B., Wandel, J., and MacDonald, J. 2006b. Vulnerability to climate change in Igloolik, Nunavut: What we can learn from the past and present. Polar Record 42(2):127-138. https://doi.org/10.1017/S0032247406005122

Ford, J.D., Pearce, T., Gilligan, J., Smit, B., and Oakes, J. 2008. Climate change and hazards associated with ice use in northern Canada. Arctic, Antarctic, and Alpine Research 40(4):647-659. https://doi.org/10.1657/1523-0430(07-040)[FORD]2.0.CO;2

Ford, J.D., Couture, N., Bell, T., and Clark, D.G. 2018. Climate change and Canada's north coast: Research trends, progress, and future directions. Environmental Reviews 26(1):82-92. https://doi.org/10.1139/er-2017-0027

Ford, J.D., Clark, D., Pearce, T., Berrang-Ford, L., Copland, L., Dawson, J., New, M., and Harper, S.L. 2019. Changing access to ice, land and water in Arctic communities. Nature Climate Change 9:335-339. https://doi.org/10.1038/s41558-019-0435-7

Gauthier, Y., Tremblay, M., Bernier, M., and Furgal, C. 2010. Adaptation of a radar-based river ice mapping technology to the Nunavik context. Canadian Journal of Remote Sensing 36(S1):S168-S185.

https://doi.org/10.5589/m10-018

Gorelick, N., Hancher, M., Dixon, M., Ilyushchenko, S., Thau, D., and Moore, R. 2017. Google Earth Engine: Planetaryscale geospatial analysis for everyone. Remote Sensing of Environment 202:18-27.

https://doi.org/10.1016/j.rse.2017.06.031

Grimwood, B.S.R., Doubleday, N.C., Ljubicic, G.J., Donaldson, S.G., and Blangy, S. 2012. Engaged acclimatization: Towards responsible community-based participatory research in Nunavut. The Canadian Geographer 56(2):211-230. https://doi.org/10.1111/j.1541-0064.2012.00416.x

Haas, C., and Druckenmiller, M.L. 2009. Ice thickness and roughness measurements. In: Eicken, H., Gradinger, R., Salganek, M., Shirasawa, K., Perovich, D., and Leppäranta, M., eds. Field techniques for sea ice research. Fairbanks, Alaska: University of Alaska Press. 49-116.

Hallikainen, M., and Winebrenner, D.P. 1992. The physical basis for sea ice remote sensing. In: Carsey, F.D., ed. Microwave remote sensing of sea ice. Geophysical Monograph Series, Vol. 68. Washington, D.C.: American Geophysical Union. 29-46. https://doi.org/10.1029/GM068p0029

Heyes, S.A. 2011. Cracks in the knowledge: Sea ice terms in Kangiqsualujjuaq, Nunavik. The Canadian Geographer 55(1):69-90.

https://doi.org/10.1111/j.1541-0064.2010.00346.x

Howell, S.E.L., Duguay, C.R., and Markus, T. 2009. Sea ice conditions and melt season duration variability within the Canadian Arctic Archipelago: 1979-2008. Geophysical Research Letters 36(10): L10502. https://doi.org/10.1029/2009GL037681

Johnson, K., and Arnold, E. 2010. Climate change adaptation action plan for Kugluktuk.

https://www.cip-icu.ca/Files/Resources/KUGLUKTUK_ CCAP_E
Kim, J.-W., Kim, D.-J., and Hwang, B.J. 2012. Characterization of Arctic sea ice thickness using high-resolution spaceborne polarimetric SAR data. IEEE Transactions on Geoscience and Remote Sensing 50(1):13-22. https://doi.org/10.1109/TGRS.2011.2160070

Kim, M., Im, J., Han, H., Kim, J., Lee, S., Shin, M., and Kim, H.C. 2015. Landfast sea ice monitoring using multisensor fusion in the Antarctic. GIScience \& Remote Sensing 52(2):239-256. https://doi.org/10.1080/15481603.2015.1026050

Krupnik, I., and Jolly, D. 2002. The Earth is faster now: Indigenous observations of Arctic environmental change. Fairbanks, Alaska: Arctic Research Consortium of the United States. $384 \mathrm{p}$.

Laidler, G.J. 2007. Ice, through Inuit eyes: Characterizing the importance of sea ice processes, use, and change around three Nunavut communities. PhD thesis, University of Toronto, Toronto, Ontario.

Laidler, G.J., and Elee, P. 2008. Human geographies of sea ice: Freeze/thaw processes around Cape Dorset, Nunavut, Canada. Polar Record 44(1):51-76. https://doi.org/10.1017/S0032247407007061

Laidler, G.J., and Ikummaq, T. 2008. Human geographies of sea ice: Freeze/thaw processes around Igloolik, Nunavut, Canada. Polar Record 44(2):127-153.

https://doi.org/10.1017/S0032247407007152

Laidler, G.J., Dialla, A., and Joamie, E. 2008. Human geographies of sea ice: Freeze/thaw processes around Pangnirtung, Nunavut, Canada. Polar Record 44(4):335-361. https://doi.org/10.1017/S003224740800750X

Laidler, G.J., Ford, J.D., Gough, W.A., Ikummaq, T., Gagnon, A.S., Kowal, S., Qrunnut, K., and Irngaut, C. 2009. Travelling and hunting in a changing Arctic: Assessing Inuit vulnerability to sea ice change in Igloolik, Nunavut. Climatic Change 94(34):363-397.

https://doi.org/10.1007/s10584-008-9512-z

Laidler, G.J., Hirose, T., Kapfer, M., Ikummaq, T., Joamie, E., and Elee, P. 2011. Evaluating the Floe Edge Service: How well can SAR imagery address Inuit community concerns around sea ice change and travel safety? The Canadian Geographer 55(1):91- 107. https://doi.org/10.1111/j.1541-0064.2010.00347.x

Lépy, E. 2008. Information and communication technologies, a tool for risk prevention and accident management on sea ice. Netcom 22(3-4):255-264.

https://doi.org/10.4000/netcom.1678

Letterly, A., Key, J., and Liu, Y. 2018. Arctic climate: Changes in sea ice extent outweigh changes in snow cover. The Cryosphere 12:3373-3382.

https://doi.org/10.5194/tc-12-3373-2018

Lindsay, R., and Schweiger, A. 2015. Arctic sea ice thickness loss determined using subsurface, aircraft, and satellite observations. The Cryosphere 9(1):269-283. https://doi.org/10.5194/tc-9-269-2015 
Lindsay, R., Haas, C., Hendricks, S., Hunkeler, P., Kurtz, N., Paden, J., Panzer, B., Sonntag, J., Yungel, J., and Zhang, J. 2012. Seasonal forecasts of Arctic sea ice initialized with observations of ice thickness. Geophysical Research Letters 39(21): L21502.

https://doi.org/10.1029/2012GL053576

Markus, T., Stroeve, J.C., and Miller, J. 2009. Recent changes in Arctic sea ice melt onset, freezeup, and melt season length. Journal of Geophysical Research: Oceans 114(C12): C12024. https://doi.org/10.1029/2009JC005436

Meier, W.N., Hovelsrud, G.K., van Oort, B.E.H., Key, J.R., Kovacs, K.M., Michel, C., Haas, C., et al. 2014. Arctic sea ice in transformation: A review of recent observed changes and impacts on biology and human activity. Reviews of Geophysics 52(3):185-217.

https://doi.org/10.1002/2013RG000431

Nickels, S., Furgal, C., Buell, M., and Moquin, H. 2005. Unikkaaqatigiit: Putting a human face on climate change. Perspectives from Inuit in Canada. Ottawa: Joint publication of Inuit Tipiriit Kanatami, Nasivvik Centre for Inuit Health and Changing Environments at Université Laval and the Ajunnginiq Centre and the National Aboriginal Health Organization.

https://www.itk.ca/wp-content/uploads/2016/07/ unikkaaqatigiit01-1.pdf

Nowell, L.S., Norris, J.M., White, D.E., and Moules, N.J. 2017. Thematic analysis: Striving to meet the trustworthiness criteria. International Journal of Qualitative Methods 16(1). https://doi.org/10.1177/1609406917733847

NTI (Nunavut Tunngavik Incorporated). 2001. Elder's conference on climate change: Final report. Cambridge Bay, Nunavut: NTI. https:/www.tunngavik.com/documents/publications/2001-0321-Elders-Report-on-Climate-Change-English.pdf

Nunavut Emergency Management. 2017. Nunavut Emergency Management annual report 2015-2016. Document No. 252-4(3). Iqaluit: Government of Nunavut.

https://assembly.nu.ca/nunavut-emergency-managementannual-report-2015-2016

Overland, J.E. 2009. Meteorology of the Beaufort Sea. Journal of Geophysical Research: Oceans 114(C1): C00A07. https://doi.org/10.1029/2008JC004861

Panikkar, B., Lemmond, B., Else, B., and Murray, M. 2018. Ice over troubled waters: Navigating the Northwest Passage using Inuit knowledge and scientific information. Climate Research 75(1):81-94.

https://doi.org/10.3354/cr01501

Perovich, D.K., Richter-Menge, J.A., Jones, K.F., and Light, B. 2008. Sunlight, water, and ice: Extreme Arctic sea ice melt during the summer of 2007. Geophysical Research Letters 35(11): L11501. https://doi.org/10.1029/2008GL034007

Pizzolato, L., Howell, S.E.L., Derksen, C., Dawson, J., and Copland, L. 2014. Changing sea ice conditions and marine transportation activity in Canadian Arctic waters between 1990 and 2012. Climatic Change 123(2):161-173.

https://doi.org/10.1007/s10584-013-1038-3
Prowse, T.D., Furgal, C., Wrona, F.J., and Reist, J.D. 2009. Implications of climate change for northern Canada: Freshwater, marine, and terrestrial ecosystems. AMBIO: A Journal of the Human Environment 38(5):282 - 289. https://doi.org/10.1579/0044-7447-38.5.282

Richter-Menge, J.A., Perovich, D.K., Elder, B.C., Claffey, K., Rigor, I., and Ortmeyer, M. 2006. Ice mass-balance buoys: A tool for measuring and attributing changes in the thickness of the Arctic sea-ice cover. Annals of Glaciology 44:205-210. https://doi.org/10.3189/172756406781811727

Rolph, R.J., Mahoney, A.R., Walsh, J., and Loring, P.A. 2018. Impacts of a lengthening open water season on Alaskan coastal communities: Deriving locally relevant indices from largescale datasets and community observations. The Cryosphere 12(5):1779-1790. https://doi.org/10.5194/tc-12-1779-2018

Scharien, R.K., Hochheim, K., Landy, J., and Barber, D.G. 2014. First-year sea ice melt pond fraction estimation from dual-polarisation C-band SAR - Part 2: Scaling in situ to RADARSAT-2. The Cryosphere 8(6):2163-2176. https://doi.org/10.5194/tc-8-2163-2014

Scharien, R.K., Segal, R., Nasonova, S., Nandan, V., Howell, S.E.L., and Haas, C. 2017. Winter Sentinel-1 backscatter as a predictor of spring Arctic sea ice melt pond fraction. Geophysical Research Letters 44(24):12262-12270. https://doi.org/10.1002/2017GL075547

Segal, R. 2019. "The best of both worlds" - connecting remote sensing and Arctic communities for safe sea ice travel. MSc thesis, University of Victoria, Victoria, British Columbia. https://dspace.library.uvic.ca//handle/1828/11129

Segal, R., Scharien, R.K., Cafarella, S., and Tedstone, A. 2020. Characterizing winter landfast sea-ice surface roughness in the Canadian Arctic Archipelago using Sentinel-1 synthetic aperture radar and the Multi-angle Imaging SpectroRadiometer. Annals of Glaciology $1-15$. https://doi.org/10.1017/aog.2020.48

SIKU. 2020. SIKU: The Indigenous knowledge social network. Sanikiluaq, Nunavut: The Arctic Eider Society. https://siku.org/about

Stammler-Gossmann, A. 2010. 'Translating' vulnerability at the community level: Case study from the Russian North. In: Hovelsrud, G.K., and Smit, B., eds. Community adaptation and vulnerability in Arctic regions. Dordrecht, Netherlands: Springer. $131-162$. https://doi.org/10.1007/978-90-481-9174-1_6

Statistics Canada. 2017a. Census profile, 2016 census: Kugluktuk, HAM [Census subdivision], Nunavut and Kitikmeot, REG [Census division], Nunavut.

http://www12.statcan.gc.ca/census-recensement/2016/dp-pd/ prof $/$ details/page.cfm?Lang $=$ E \&Geol $=$ CSD\&Code $1=620805$ $9 \&$ Geo $2=$ CD\&Code $2=6208 \&$ Data $=$ Count $\&$ SearchText $=$ kug luktuk $\&$ SearchType $=$ Begins $\&$ SearchPR $=01 \& B 1=A 11 \& T A B$ $\mathrm{ID}=1$ 
2017b. Census profile, 2016 census: Cambridge Bay, HAM [Census subdivision], Nunavut and Kitikmeot, REG [Census division], Nunavut.

http://www12.statcan.gc.ca/census-recensement/2016/dp-pd/ prof/details/page.cfm?Lang $=\mathrm{E} \&$ Geol $=\mathrm{CSD} \&$ Code $1=6208073$ $\& \mathrm{Geo} 2=\mathrm{CD} \& \mathrm{Code} 2=6208 \&$ Data $=$ Count $\&$ SearchText $=\mathrm{Camb}$ ridge $\% 20$ Bay $\&$ SearchType $=$ Begins $\&$ SearchPR $=01 \& B 1=A 11 \&$ GeoLevel $=$ PR \&GeoCode $=6208073 \&$ TABID $=11$

Steele, M., Ermold, W., and Zhang, J. 2008. Arctic Ocean surface warming trends over the past 100 years. Geophysical Research Letters 35(2): L02614.

https://doi.org/10.1029/2007GL031651

Stephenson, S.R., Smith, L.C., and Agnew, J.A. 2011. Divergent long-term trajectories of human access to the Arctic. Nature Climate Change 1(3):156-160.

https://doi.org/10.1038/nclimate1120

Stroeve, J.C., Markus, T., Boisvert, L., Miller, J., and Barrett, A. 2014. Changes in Arctic melt season and implications for sea ice loss. Geophysical Research Letters 41(4):1216-1225.

https://doi.org/10.1002/2013GL058951
Stuckenberger, A.N. 2010. Les Inuit et le changement climatique. Études/Inuit/Studies 34(1):5-19.

https://doi.org/10.7202/045400ar

Teleti, P.R., and Luis, A.J. 2013. Sea ice observations in polar regions: Evolution of technologies in remote sensing. International Journal of Geosciences 4(7):1031 - 1050. https://doi.org/10.4236/ijg.2013.47097

Tondu, J.M.E., Balasubramaniam, A.M., Chavarie, L., Gantner, N., Knopp, J.A., Provencher, J.F., Wong, P.B.Y., and Simmons, D. 2014. Working with northern communities to build collaborative research partnerships: Perspectives from early career researchers. Arctic 67(3):419-429. https://doi.org/10.14430/arctic4416

Wu, B., Wang, J., and Walsh, J.E. 2006. Dipole anomaly in the winter Arctic atmosphere and its association with sea ice motion. Journal of Climate 19(2):210-225.

https://doi.org/10.1175/JCLI3619.1 